\title{
Malnutrition in Patients with Liver Cirrhosis
}

\author{
Julia Traub ${ }^{1}{ }^{\mathbb{C}}$, Lisa Reiss ${ }^{1}$, Benard Aliwa ${ }^{2}$ and Vanessa Stadlbauer ${ }^{2, *}$ \\ 1 Department of Clinical Medical Nutrition, University Hospital Graz, 8036 Graz, Austria; \\ Julia.Traub@klinikum-graz.at (J.T.); lisamaria.reiss@edu.fh-joanneum.at (L.R.) \\ 2 Department of Gastroenterology and Hepatology, Medical University of Graz, 8036 Graz, Austria; \\ benard.aliwa@medunigraz.at \\ * Correspondence: vanessa.stadlbauer@medunigraz.at; Tel.: +43-316-385-82282
}

Citation: Traub, J.; Reiss, L.; Aliwa, B.; Stadlbauer, V. Malnutrition in Patients with Liver Cirrhosis. Nutrients 2021, 13, 540. https:// doi.org/10.3390/nu13020540

Academic Editors: Ina Bergheim and Roberto Iacone

Received: 4 December 2020

Accepted: 4 February 2021

Published: 7 February 2021

Publisher's Note: MDPI stays neutral with regard to jurisdictional claims in published maps and institutional affiliations.

Copyright: (c) 2021 by the authors. Licensee MDPI, Basel, Switzerland. This article is an open access article distributed under the terms and conditions of the Creative Commons Attribution (CC BY) license (https:// creativecommons.org/licenses/by/ $4.0 /)$.

\begin{abstract}
Liver cirrhosis is an increasing public health threat worldwide. Malnutrition is a serious complication of cirrhosis and is associated with worse outcomes. With this review, we aim to describe the prevalence of malnutrition, pathophysiological mechanisms, diagnostic tools and therapeutic targets to treat malnutrition. Malnutrition is frequently underdiagnosed and occurs-depending on the screening methods used and patient populations studied-in 5-92\% of patients. Decreased energy and protein intake, inflammation, malabsorption, altered nutrient metabolism, hypermetabolism, hormonal disturbances and gut microbiome dysbiosis can contribute to malnutrition. The stepwise diagnostic approach includes a rapid prescreen, the use of a specific screening tool, such as the Royal Free Hospital Nutritional Prioritizing Tool and a nutritional assessment by dieticians. General dietary measures-especially the timing of meals-oral nutritional supplements, micronutrient supplementation and the role of amino acids are discussed. In summary malnutrition in cirrhosis is common and needs more attention by health care professionals involved in the care of patients with cirrhosis. Screening and assessment for malnutrition should be carried out regularly in cirrhotic patients, ideally by a multidisciplinary team. Further research is needed to better clarify pathogenic mechanisms such as the role of the gut-liver-axis and to develop targeted therapeutic strategies.
\end{abstract}

Keywords: malnutrition; cirrhosis; nutritional screening; nutritional assessment; gut-liver axis; macronutrients; micronutrients; dysbiosis

\section{Introduction}

The Hepahealth report from 2018 reported a prevalence of chronic liver disease and cirrhosis in Europe between 500 and 1100 cases per 100.000 inhabitants [1]. Data from the USA show a 65\% increase in cirrhosis associated mortality between 1999 and 2016 [2]. Cirrhosis is a systemic disease and malnutrition is a key feature as well as an important complication of the disease. This implicates that malnutrition diagnosis is not only relevant as one of the clinical characteristics of cirrhosis, but also needs to be considered as an important complication, that warrants timely and appropriate therapy to improve prognosis. Our review should highlight the importance of early diagnosis, should help to understand the pathophysiology and define appropriate therapeutic measures. Additionally, knowledge gaps are identified. In this review the term malnutrition is used to describe undernutrition. The discussion of overnutrition in liver disease is beyond the scope of this review.

The reported prevalence of malnutrition in cirrhosis is highly variable, ranging from $5-92 \%$, indicating either a knowledge gap or difficulties in diagnosing malnutrition or both. The knowledge gap is underpinned by a survey, in which only $20 \%$ of gastroenterologists gave correct answers regarding the prevalence of malnutrition in cirrhotic patients [3]. The problem of underdiagnosis can be derived from two very large studies from the USA using the national inpatient sample, that showed a much lower prevalence of $6-12 \%$, whereas studies that used active screening for malnutrition exhibit higher rates of detection $[4,5]$. Supplementary Table S1 summarizes studies describing the prevalence of malnutrition 
in cirrhosis over the past five years, depicting the large differences depending on the study design and the tools used for diagnosis. Malnutrition should therefore be routinely screened for and assessed among this group of high-risk patients to avoid underdiagnosis. However, screening of malnutrition in liver cirrhosis patients is challenging because of the influence of fluid retention, ascites and peripheral edema [5]. Malnutrition prevalence, as a key feature of cirrhosis, increases with increasing disease severity [6,7]. However, frequently also patients with compensated liver disease are malnourished and malnutrition is a considerable risk factor for mortality even in patients with a model of end-stage liver disease (MELD) score < 15 [8]. Furthermore, patients with chronic liver disease but without cirrhosis are also frequently malnourished [9]. In this population, malnutrition may often be masked by obesity [9]. Malnutrition can also be seen as a complication of cirrhosis, since it has a negative impact on disease progression and outcome. Rate of hospitalization and mortality is doubled in malnourished compared to adequately nourished patients and malnutrition is an independent predictor of outcome [10-12]. Malnutrition is a predictor of other complications of cirrhosis [13]. Especially infections and hepatic encephalopathy are associated with malnutrition [14,15]. Furthermore, other malnutrition related diagnoses, namely sarcopenia, hepatic osteodystrophy and frailty are commonly found in liver cirrhosis. The presence of sarcopenia further impairs prognosis [16-25]. The interplay between malnutrition, sarcopenia and frailty has recently been reviewed [26].

This review summarizes the current knowledge on pathogenesis of malnutrition in cirrhosis and discusses the best clinically applicable strategies to diagnose malnutrition in order to raise awareness for this still often underappreciated complication of cirrhosis. Treating malnutrition by a multidisciplinary team improves survival rates and quality of life in patients with liver cirrhosis [27] and nutritional education leads to more nutrition consultations and a lower 90-day readmission rate in cirrhosis [28]. Therefore this review also discusses current and potential future therapeutic options to treat malnutrition in cirrhosis.

\section{Pathogenesis}

The etiology of malnutrition in liver cirrhosis is multifactorial (Figure 1). Decreased energy and protein intake, inflammation, malabsorption, altered nutrient metabolism, hormonal disturbances, hypermetabolism and gut microbiome dysbiosis can contribute to malnutrition. Additionally, fasting periods and external factors such as alcohol consumption have impact on malnutrition.

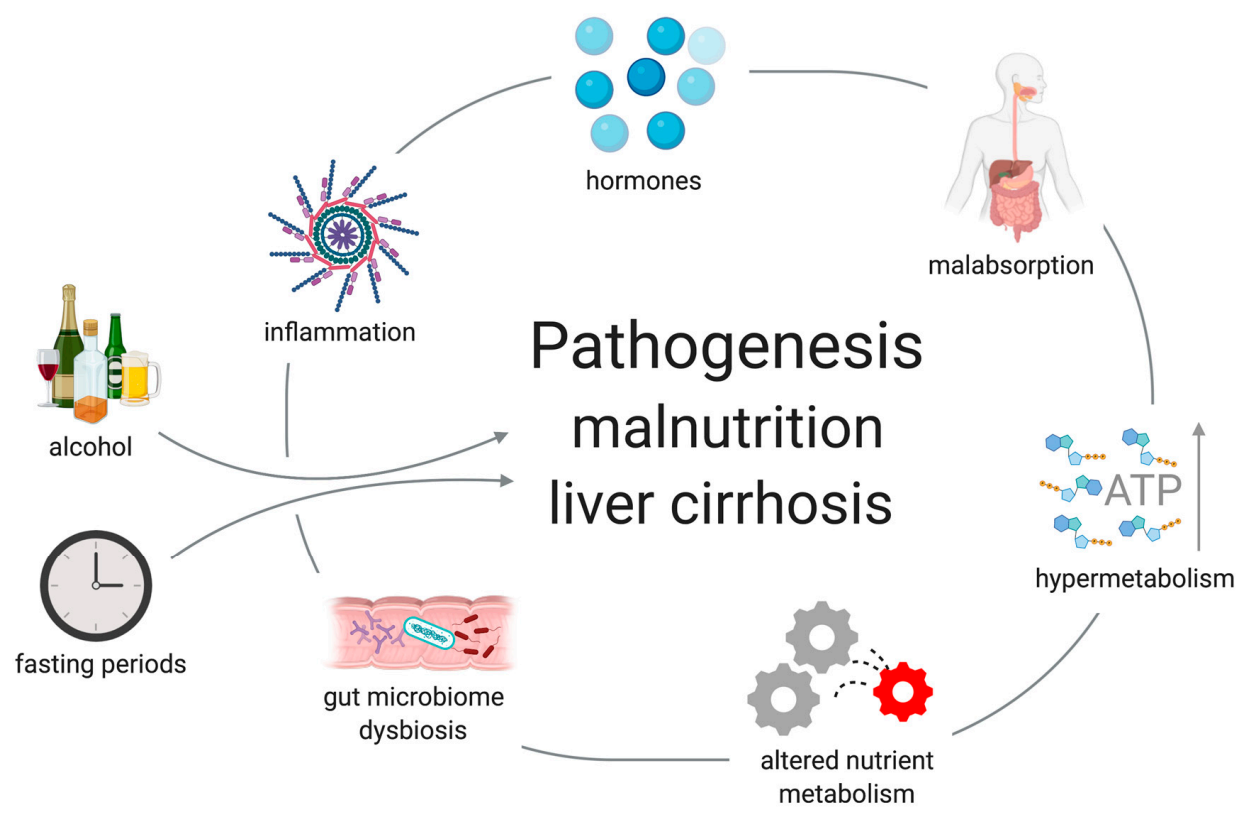

Figure 1. Factors contributing to malnutrition in cirrhosis. Created with BioRender.com. 


\subsection{Decreased Energy and Protein Intake}

In patients with liver cirrhosis, decreased energy and protein intake are the commonest reason leading to malnutrition [29-35]. The percentage of patients with inadequate energy intake ranges from $9.2 \%$ to $100 \%$ in different studies, depending on the method of assessment and the patient population. Energy intake is reduced by $13-34 \%$, indication a large variation in different studies. Supplementary Table S2 shows the design and results of different studies assessing nutritional intake. Several upstream mechanisms are known as reasons for decreased energy and protein intake (Figure 2). Impaired gastric motility and relaxation due to portal hypertension leads to reduced nutritional intake [36,37]. The presence of ascites can reduce food intake due to early feeling of fullness [38]. A decreased sense of smell and/or dysgeusia, which can be caused by micronutrient deficiencies can also be responsible for a decreased intake $[39,40]$. Additionally, recommended dietary restriction like a low-salt diet are discussed as possible factors for inadequate nutritional intake [41,42]. In cirrhosis, interestingly, high levels of ghrelin were observed [31,43,44]. Ghrelin is the only known peripherally-derived orexigenic hormone that normally increases appetite and food intake. However, despite high ghrelin levels, appetite is not increased in cirrhotic patients. High ghrelin levels can therefore be considered as an ineffective compensatory mechanism in cirrhosis [31]. To date, it is unknown, which of these factors plays the most important role. Therefore, all factors should be considered during the assessment of nutritional intake in each patient as a personalized approach to detect and adequately treat the most likely reasons for reduced nutritional intake.

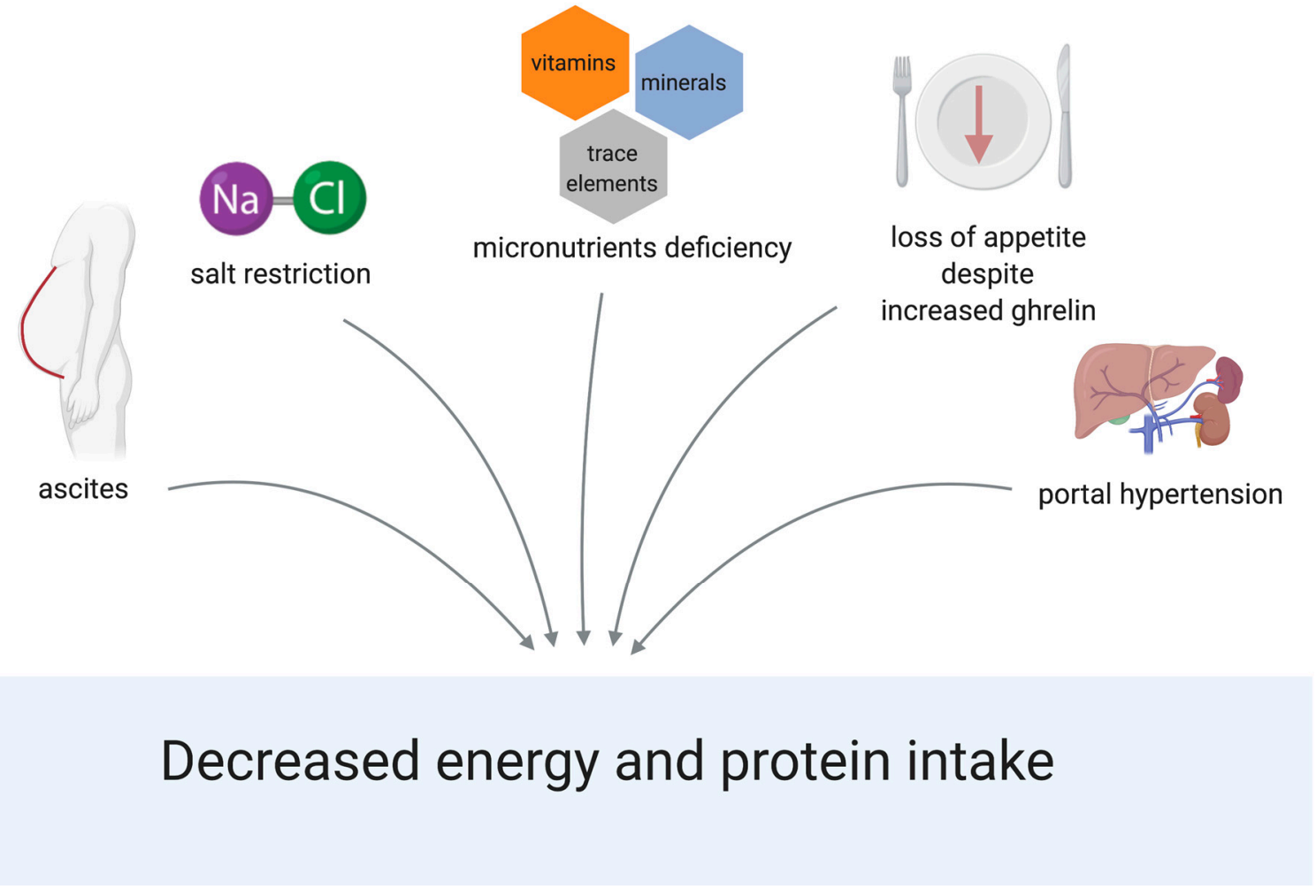

Figure 2. Reasons for decreased energy and protein intake in cirrhosis. Created with BioRender.com.

\subsection{Malabsorption and Altered Metabolism of Macro- and Micronutrients}

Fat malabsorption is commonly seen in cirrhosis $[45,46]$. Impaired bile acid metabolism which affects the formation of micelles that are necessary for fat digestion and absorption of fat-soluble vitamins, $[47,48]$ small intestinal bacterial overgrowth, which is common in liver cirrhosis patients, [49] can lead to fat malabsorption via deconjugation of bile acids [50]. Chronic pancreatitis, secondary to alcohol abuse and common in liver cirrhosis 
patients, may contributes to fat malabsorption as well [51,52]. Protein loss due to portal hypertensive enteropathy has been described [53-55]. No data is available regarding impairment of carbohydrate absorption in cirrhosis. Malabsorption needs to be considered in the nutritional assessment and diagnosed, using biomarkers such as fecal elastase or fecal alpha-1-antitrypsin and tests for micronutrient deficiencies (see below). A useful stepwise diagnostic algorithm, starting with noninvasive routine blood tests and specific biomarkers has been proposed by Nikaki K. in 2016 [56].

In addition to altered absorption, also fat, protein and carbohydrate metabolism are altered in cirrhosis, with differing mechanisms depending on the etiology. Much research has been done to elucidate the mechanisms: chronic alcohol consumption alters lipid metabolism by stimulating lipogenesis, decreasing the export of very low-density lipoprotein, activate de novo lipogenesis and inhibiting fatty acid oxidation which also contributes to alcoholic fatty liver disease [57-61]. Alcohol consumption also impairs fatty acid catabolism predominantly through inhibition of mitochondrial ß-oxidation, which is the most significant contribution to alcohol-induced hepatic lipid accumulation and leads to triglyceride accumulation in the liver [62-64]. Also in non-alcoholic fatty liver disease, adipose tissue and hepatic triglyceride metabolism is altered [65]. Protein metabolism is impaired due to increased protein catabolism and decreased protein synthesis. Furthermore, decreased serum branched chained amino acids (BCAA) concentration and increased levels of aromatic amino acids are observed in cirrhosis, which play a role in the pathogenesis of hepatic encephalopathy and muscle wasting [66-70]. Glucose metabolism is severely altered as well: peripheral insulin resistance but normal or enhanced uptake into the liver as well as alterations in glycolytic enzymes and changes in glucose and insulin transporters have been described. This contributes to decreased hepatic glucose production and lower hepatic glycogen reserves, associated with increased gluconeogenesis from amino acids and secondary protein breakdown. The above described metabolic abnormalities in carbohydrate metabolism also lead to a state of accelerated starvation already after an overnight fast [71-76]. The role of portal hypertension and portosystemic shunting in protein energy metabolism is not fully elucidated yet: on the one hand, the placement of a transjugular intrahepatic portosystemic shunt can lead to improvement of fat free mass and thereby prognosis [77-79]. On the other hand, there is also evidence that portosystemic shunting may have deleterious nutritional effects due to a reduction in hepatic nutrient flow [80]. While the molecular principles of changes in macronutrient metabolism in cirrhosis are already well described, the direct therapeutic implications of these findings are not well defined yet. Timing and composition of meals as therapeutic measures to account for changes in macronutrient metabolism are described below. Further research is needed to understand the effect of portal hypertension and portosystemic shunting in humans on protein anabolism and catabolism including the role of the gut-liver axis.

But not only macronutrient metabolism is altered in liver cirrhosis patients. Deficiencies in trace elements, minerals and vitamins are common, due to fat malabsorption, diuretic use and inadequate intake. In addition, liver dysfunction itself can lead to alterations in trace element metabolism [81,82]. Zinc, selenium, iron and magnesium are commonly decreased in liver cirrhosis [83-88] whereas copper and manganese can be increased [81,89]. Fat-soluble vitamin deficiencies are common in liver cirrhosis [90] which can in turn impair absorption of other nutrients, such as protein and fat [91]. For the absorption of fat-soluble vitamins, bile acids are required to form micelles which are absorbed by enterocytes into the circulation. If there is inadequate delivery of bile acids, as it is common in liver cirrhosis patients, this can lead to a deficiency of fat-soluble vitamins, especially in jaundiced patients [92,93]. Trace element and vitamin deficiencies can in turn impact negatively on nutrition intake indicating a vicious cycle of malnutrition in cirrhosis: zinc and vitamin A deficiency can impair taste and olfaction and therefore impair food intake. [39,94] Vitamin D deficiency is of prognostic relevance, since it is associated with poor outcome, increased mortality and higher complications rate, however it is yet unclear whether vitamin D levels are a mere surrogate of advanced liver disease or if there exists a 
direct pathophysiological relation [95-98]. Water-soluble vitamins, especially vitamins C, B1, B2, B6 and folic acid [99-101] are decreased whereas vitamin B12 levels can be falsely increased in liver cirrhosis, possibly due to a flooding of vitamin B12 from damaged liver cells into the circulation [102,103]. For a summary of changes of micronutrients in cirrhosis see Supplementary Table S3.

Not only are absorption and metabolism altered, but also energy expenditure contributes to malnutrition: $15-30 \%$ of cirrhotic patients are hypermetabolic with a resting energy expenditure of $>120 \%$, which negatively effects nutrition status [104-107]. Hypermetabolism compromises overall transplant-free and early post-transplant survival [108-110]. The cause of hypermetabolism in liver cirrhosis is not yet clarified in full detail. From rheumatoid disease it is known that inflammation drives hypermetabolism [111]. Elevated levels of interleukin-1, interleukin- 6 and transforming growth factor are also common in chronic alcoholic liver diseases [112-116]. Therefore, inflammation can be considered as a contributing factor to hypermetabolism and malnutrition [117], alongside with increased beta-adrenergic activity [72]. Additionally, elevated levels of proinflammatory cytokines may be directly responsible for decreased appetite $[118,119]$. Since inflammation in cirrhosis is tightly linked to changes in the gut-liver axis, [120-122] the relation to hypermetabolism needs further research to elucidate pathophysiology and define possible therapeutic interventions.

Hormones, as superordinate control of nutritional intake and metabolism also impact on nutrition in cirrhosis. The role of ghrelin in appetite regulation was already described above. In addition, ghrelin has a wide spectrum of other metabolic functions in glucose metabolism and weight control and posttranslational modification is essential to exert its metabolic function. The diverse roles of ghrelin in liver disease has recently been extensively reviewed [123]. Ghrelin as well as leptin are known to influence energy expenditure $[124,125]$. Leptin, which helps to regulate energy balance, circulates in free and bound form. The basal concentrations of leptin are higher in patients with liver cirrhosis and can lead to inadequate energy expenditure [126]. Hyperinsulinemia and insulin resistance are also common in liver cirrhosis; increased insulin levels induce satiety, leading to a reduction in energy intake [127]. Testosterone is reduced in about $90 \%$ of men with liver cirrhosis [128] and plays an important role in protein synthesis and protein breakdown [129].

\subsection{Gut Microbiome Dysbiosis as Potential Contributor to Malnutrition}

Altered nutritional status is associated with distinct gut microbiome dysbiosis in cirrhosis [130]. The gut microbiome is a nutrient signal transducer with the capacity to synthesize or modify nutrient signaling molecules such as short-chain fatty acid (SCFA) and branched chain amino acid (BCAA) [131,132]. Several bacterial genera are known to produce SCFA, such as Bacteroides, Faecalibacterium, Succinivibrio and Butyricimonas among others $[133,134]$. Undernourished children for example showed a lower abundance of different Bacteroides species, suggesting a loss in SCFA-producing species $[135,136]$. In cirrhosis, SCFA-producing bacterial species are reduced [137]. The observed alteration in the gut microbiome composition in cirrhosis is associated with increased protein catabolism mediated by inflammatory responses leading to muscle loss [138]. Gut microbiome dysbiosis is further associated with increased gut permeability and bacterial translocation, which is associated with inflammation [122] and complications of cirrhosis [122,139,140]. It is not known to date whether gut microbiome dysbiosis precedes the development of malnutrition in cirrhosis or if it is a consequence of the disease and the drug treatment of the disease. This question would be of high relevance to answer, in order to develop microbiome targeted therapeutic strategies to improve malnutrition in the clinical setting. 


\section{Diagnosis}

Since malnutrition is a common key feature and a complication of liver cirrhosis and related to a poor prognosis, early diagnosis is important. Unfortunately, the common models to determine the prognosis in patients with liver cirrhosis, such as the model of end-stage liver disease (MELD) [141] and the Child-Pugh score [142], do not include nutritional screening or assessment. Of note, the original score developed by the surgeons Child and Turcotte, contained malnutrition as a variable, which was later substituted by prothrombin time [143]. All liver cirrhosis patients should be rapidly prescreened for the risk of malnutrition at each contact by assessing Child-Pugh score and BMI and when at high risk (Child-Pugh score C irrespective of the BMI or BMI $<18.5 \mathrm{~kg} / \mathrm{m}^{2}$ irrespective of the Child-Pugh score) a nutritional assessment, including assessment of sarcopenia as a complication of malnutrition, should be completed immediately to confirm the presence and determine the severity of malnutrition [144-146]. This prescreening can be done by skilled personnel from different disciplines, since it contains routine clinical data, which are normally collected at each outpatient visit or at hospitalization. In the future, automated prescreening combining routinely assessed data from electronic patient records, is thinkable. A specific screening tool, which is validated for patients with liver cirrhosis, is advised to account for special circumstances such as fluid retention in cirrhosis. The Royal Free HospitalNutritional Prioritizing Tool (RFH-NPT) fulfills this requirement $[145,147]$. Common malnutrition screening tools for the general hospital population do not perform well in cirrhosis [148]. If a general malnutrition tool is intended to be used in cirrhosis, it needs to be validated first. In patients with medium or high risk in the RFH-NPT (1 point or more), a detailed nutritional assessment using cirrhosis specific assessment tools such as the Subjective Global Assessment or the Royal Free Hospital Global Assessment as well as a detailed assessment of dietary intake are required $[145,147]$. In patients, who are at high risk for malnutrition, the assessment of sarcopenia in addition to a detailed nutritional assessment is recommended to confirm and characterize complications of malnutrition and identify modifiable variables for nutrition support. Methods for the assessment of sarcopenia in liver cirrhosis have recently been reviewed [149]. In obese patients with cirrhosis Child-Pugh A or B $\left(\mathrm{BMI}>30 \mathrm{~kg} / \mathrm{m}^{2}\right)$, a nutritional and lifestyle intervention targeting obesity is indicated $[145,147]$. As nutritional assessment is more comprehensive, time consuming and requires interpretation of multiple nutrition indicators, it should be performed by a dietitian [150]. In patients with low risk of malnutrition, rescreening should be performed every year, in all other patients the assessment should be repeated every one to six months in the outpatient setting and at admission and for inpatients periodically during the hospital stay [145]. Figure 3 shows a comprehensive algorithm to screen for and assess malnutrition in cirrhosis, adapted from the European Association for the Study of the Liver (EASL) clinical practices guidelines [145]. 


\section{Cirrhosis / advanced chronic liver disease}

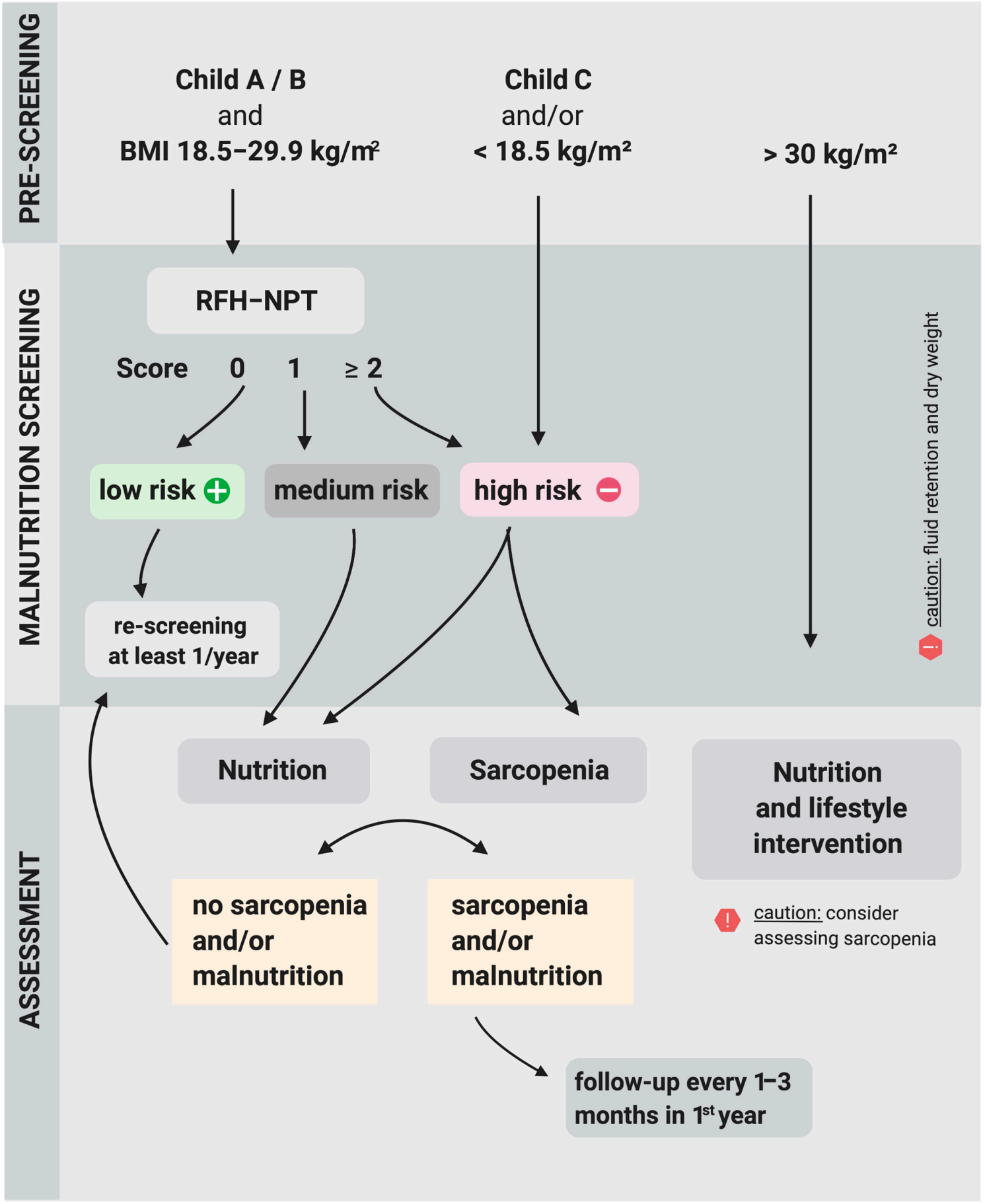

Figure 3. Algorithm to screen for and assess malnutrition in cirrhosis, adapted from the European Association for the Study of the Liver (EASL) clinical practices guidelines [145]. Created with BioRender.com. 


\section{Therapeutic Strategies}

\subsection{Diet}

The positive effect of dietary interventions on prognosis in cirrhosis has been clearly shown: optimizing the nutritional status of liver cirrhosis patients improves morbidity and mortality $[13,17,151-153]$ even in patients with acute on chronic liver failure [154]. Nutritional therapeutic interventions by a multidisciplinary team, especially through dietary counseling from dieticians, improves biomarkers of malnutrition, $[155,156]$ quality of life [27,157] and survival rate [27].

The recommended macronutrient composition in cirrhosis mainly focusses on protein intake. Cirrhotic patients have an increased protein requirement based on the increased protein turnover and catabolism $[158,159]$. A high protein intake improves in nutritional status $[155,160]$. Even patients with hepatic encephalopathy, where in the past protein restriction was advocated, [161] benefit from normal to high protein intake [157,162-165]. The recommendations regarding protein intake differ slightly, but not relevantly, between different guidelines, depending on the nutritional status and range from $1.2-1.5 \mathrm{~g}$ protein $/ \mathrm{kg}$ bodyweight (Table 1). There are no specific recommendations regarding carbohydrate and fat intake for patients with liver cirrhosis.

Table 1. Summary of dietary recommendations in cirrhosis from different populations.

\begin{tabular}{|c|c|c|}
\hline \multirow{3}{*}{ Energy } & General cirrhosis patients & $>35 \mathrm{kcal} / \mathrm{kg}$ bodyweight ${ }^{1}$ \\
\hline & Malnourished cirrhosis patients & $30-35 \mathrm{kcal} / \mathrm{kg}$ bodyweight $^{3}$ \\
\hline & Cirrhosis patients with HE & $35-40 \mathrm{kcal} / \mathrm{kg}$ bodyweight $1,2,4$ \\
\hline \multirow{4}{*}{ Protein } & General cirrhosis patients & $1.2-1.5 \mathrm{~g} / \mathrm{kg}$ bodyweight ${ }^{1}$ \\
\hline & $\begin{array}{l}\text { Replenish malnourished and/or sarcopenic } \\
\text { cirrhosis patients }\end{array}$ & $1.5 \mathrm{~g} / \mathrm{kg}$ bodyweight ${ }^{3}$ \\
\hline & Nonmalnourished cirrhosis patients & $1.2 \mathrm{~g} / \mathrm{kg}$ bodyweight per day ${ }^{3}$ \\
\hline & Cirrhosis patients with $\mathrm{HE}$ & $\begin{array}{l}1.2-1.5 \mathrm{~g} / \mathrm{kg} \text { bodyweight } \\
\text { no protein restriction }^{3}\end{array}$ \\
\hline Fat & & No specific recommendations \\
\hline \multirow[b]{2}{*}{ Carbohydrates } & & No specific recommendations \\
\hline & Cirrhosis patients with $\mathrm{HE}$ & $\begin{array}{l}25-45 \mathrm{~g} \text { of fiber }{ }^{4} \\
\text { Late evening snack with } 50 \mathrm{~g} \\
\text { complex carbohydrates }{ }^{4}\end{array}$ \\
\hline \multirow{3}{*}{ Dietary pattern } & General cirrhosis patients & $\begin{array}{l}3-5 \text { meals a day }{ }^{3} \\
\text { Late evening snack }\end{array}$ \\
\hline & $\begin{array}{l}\text { Malnourished decompensated cirrhotic } \\
\text { patients }\end{array}$ & Late evening ONS and breakfast ${ }^{1}$ \\
\hline & Cirrhosis patients with $\mathrm{HE}$ & $\begin{array}{l}\text { Small meals evenly distributed } \\
\text { throughout the day } 2,4 \\
\text { Late- night snack } 2,4\end{array}$ \\
\hline Salt & & $\begin{array}{l}\text { "No added salt" diet with } 5-6 \text { g salt per } \\
\text { day, care should be taken when salt } \\
\text { reduction leads to reduced palatability }{ }^{1,3}\end{array}$ \\
\hline
\end{tabular}

HE, hepatic encephalopathy; ONS oral nutritional supplements. ${ }^{1}$ European Association for the Study of the Liver (EASL). ${ }^{2}$ American Association for the Study of Liver Diseases (AASLD). ${ }^{3}$ European Society for Clinical Nutrition and Metabolism (ESPEN). ${ }^{4}$ International Society for Hepatic Encephalopathy and Nitrogen Metabolism Consensus (ISHEN).

Current evidence suggests that timing and frequency of meals is of importance to improve malnutrition in cirrhosis. After overnight fasting, glycogen stores in cirrhotic livers are emptied [74]. A late evening snack with $50 \mathrm{~g}$ complex carbohydrates can improve 
nitrogen metabolism, increase lean body mass and reverse anabolic resistance and sarcopenia [166-169]. Eating breakfast improves cognitive function in cirrhosis, indicating that, depending on personal preferences in dietary habits, an individualized approach for timing of meals should be developed during dietary counselling [170]. A higher frequency of 5-6 meals/day also shortens episodes of catabolism during the day [171]. It is particularly important to pay attention to the timing and frequency of meals in hospitalized patients to avoid long and often unnecessary "nil per os" periods due to planned diagnostic tests.

The main emphasis in dietary counselling should be to ensure adequate oral intake. If oral intake including oral nutrition supplements (see below) is insufficient despite adequate nutritional advice, enteral tube feeding may be considered for cirrhotic patients to achieve their nutritional and energy goals [172]. Nonbleeding esophageal varices are no contraindication for the placement of a nasogastric tube [163,173]. An endoscopic gastrostomy, on the other hand, is associated with a higher risk of complications, especially bleeding, and is therefore not recommended for patients with advanced chronic liver disease [174]. In moderately or severely malnourished cirrhosis patients, who are unable to eat oral food or cannot be fed sufficiently enterally, parenteral nutrition should be started according to the ESPEN recommendations [175]. Additionally, parenteral nutrition should be given when fasting periods last longer than $72 \mathrm{~h} \mathrm{[175].} \mathrm{Since} \mathrm{cirrhotic} \mathrm{patients} \mathrm{are} \mathrm{more}$ prone to sepsis or infections, care should be taken to avoid infections from central venous lines [176].

When ascites is diagnosed in patient with liver cirrhosis, a "no added salt" diet restricted to $90 \mathrm{mmol}$ salt per day ( $5.2 \mathrm{~g}$ ) is recommended by many guidelines. However, as we recently reviewed in detail, a low-sodium diet, although leading to a faster disappearance of ascites and less need for diuretics can lead to poor diet adherence because of impaired taste of the meals, reduced energy and protein intake and increased risk of malnutrition [42]. Therefore the risks and benefits of salt restriction have to be weighed carefully in each patient, again showing the necessity of a multidisciplinary team approach to treat malnutrition in cirrhosis.

\subsection{Oral Nutritional Supplements and Micronutrients Supplementation}

Oral nutritional supplements can help to achieve nutritional goals in cirrhosis. A significant improvement in anthropometric nutritional parameters such as lean muscle mass and body mass index as well as serum proteins can be achieved by oral nutritional supplements $[160,177]$. A meta-analysis concluded that oral nutritional supplements may also improve outcome [152]. Furthermore, an improvement in quality of life, functional status and rehabilitation of malnourished cirrhosis patients can be achieved $[157,178]$. In terms of administration time, nocturnal oral nutritional supplements have a better effect in improving the total body protein status than at daytime [166] (Table 2). Since oral nutritional supplements also contain micronutrients and vitamins, this may be of additional benefit in patients with cirrhosis, however, so far no clear benefit of micronutrient supplementation could be shown [179]. Moreover, no clinical data comparing different products are available, therefore choice can be based on personal preference and price.

Although some studies demonstrate the positive effect of micronutrients supplementation, due to the lack of robust data, no clear recommendations can be made. Additional supplementation is currently only recommended in cases of confirmed or clinically suspected deficiency. Data on zinc supplementation is conflicting: some studies report positive effects on zinc supplementation in hepatic encephalopathy [180-182], while others report no significant improvements [183,184]. Zinc supplementation in case of deficiency improves liver function and nutritional status $[185,186]$ and may even impact positively on clinical outcome $[187,188]$. Normalizing zinc and vitamin A levels can also indirectly improve the nutritional status by a positive effect on sense of taste and thereby increased food intake [94,189]. A meta-analysis found no evidence to support or refute antioxidant supplements such as beta-carotene, vitamins A, C, E and selenium in liver disease [179]. Also, for vitamin D supplementation, evidence is not sufficient. Vitamin D deficiency is 
common in cirrhosis and associated with increased mortality [190] and deficiency can be corrected by oral supplementation in cirrhosis [191,192]. However, due to inadequate overall data quality, there is not sufficient evidence to prove or disprove an effect on morbidity and quality of life of vitamin D supplementation [193] (Table 2).

Table 2. Summary of recommendations for oral nutritional supplements, micronutrient supplementation and branched chain amino acid (BCAA) supplementation from different populations.

\begin{tabular}{|c|c|c|}
\hline \multirow[b]{2}{*}{ Oral nutritional supplements } & General cirrhosis patients & Late evening oral nutritional supplement ${ }^{1}$ \\
\hline & Cirrhosis patients with $\mathrm{HE}$ & $\begin{array}{l}\text { Liquid nutritional supplements evenly distributed } \\
\text { throughout the day }{ }^{2}\end{array}$ \\
\hline \multirow[t]{2}{*}{ Micronutrient supplements } & General cirrhosis patients & $\begin{array}{l}\text { Administration of micronutrients to treat confirmed or } \\
\text { clinically suspected deficiency } 1,3 \\
\text { Assessment of vitamin D levels based on frequent } \\
\text { deficiency and supplement at vitamin D levels }<20 \mathrm{ng} / \mathrm{mL} \text {, } \\
\text { to reach serum vitamin D }(25(\mathrm{OH}) \mathrm{D})>30 \mathrm{ng} / \mathrm{mL}^{1}\end{array}$ \\
\hline & Cirrhosis patients with $\mathrm{HE}$ & $\begin{array}{c}\text { For patients with decompensated cirrhosis or those at risk } \\
\text { for malnutrition a } 2 \text {-week course of a multivitamin } \\
\text { preparation could be justified } \\
\text { Specific treatment of clinically apparent } \\
\text { vitamin deficiencies } 4\end{array}$ \\
\hline \multirow[t]{2}{*}{ Amino acids } & General cirrhosis patients & $\begin{array}{l}\text { Decompensated cirrhosis: BCAA supplements and leucine } \\
\text { enriched amino acid supplements when inadequate } \\
\text { nitrogen intake by oral diet }{ }^{1} \\
\text { Oral vegetable proteins or BCAA }(0.25 \mathrm{~g} / \mathrm{kg} \\
\text { bodyweight/day) for cirrhosis patients who are protein } \\
\text { "intolerant" to facilitate adequate protein intake }{ }^{3} \\
\text { Long-term oral BCAA supplements }(0.25 \mathrm{~g} / \mathrm{kg} \\
\text { bodyweight/day) in patients with advanced cirrhosis in } \\
\text { order to improve event-free survival or quality of life }{ }^{3}\end{array}$ \\
\hline & Cirrhosis patients with $\mathrm{HE}$ & $\begin{array}{l}\text { BCAA supplementation for improving neuropsychiatric } \\
\text { performance and to reach the recommended } \\
\text { nitrogen intake } 1 \\
\text { Oral BCAA supplementation for cirrhosis patients who are } \\
\text { "intolerant" of dietary protein to achieve and maintain } \\
\text { recommended nitrogen intake } \\
\text { rect }\end{array}$ \\
\hline
\end{tabular}

HE, hepatic encephalopathy; BCAA, branched chain amino acids. ${ }^{1}$ European Association for the Study of the Liver (EASL). ${ }^{2}$ American Association for the Study of Liver Diseases (AASLD). ${ }^{3}$ European Society for Clinical Nutrition and Metabolism (ESPEN). ${ }^{4}$ International Society for Hepatic Encephalopathy and Nitrogen Metabolism Consensus (ISHEN).

\subsection{Amino Acids}

BCAA serum levels are low in cirrhosis because they are preferentially used as energy substrates, but are also essential for protein synthesis and ammonia detoxification [194]. BCAA supplementation has been shown to prevent lipolysis and proteolysis and improves nitrogen balance, muscle mass, nutritional status, complication free survival, quality of live and hepatocellular carcinoma risk [194-202]. However, despite this quite clear evidence of positive effects, current guidelines recommend BCAA supplementation only in decompensated cirrhosis, when adequate protein intake cannot be achieved by oral diet or in case of complications. For hepatic encephalopathy, vegetarian protein, which is rich in BCAA, is considered to be the ideal protein source, not only because it is better tolerated than animal protein $[164,203,204]$ but also because vegetarian protein may positively influence gut microbiome composition [205]. BCAA can also be used as late evening snack to improve nutritional status [73] especially in protein-intolerant patients [144-146,206] (Table 2).

\section{Summary}

Malnutrition is a common and dangerous key feature and complication of liver cirrhosis. Diagnosis is challenging and often overlooked. A repetitive diagnostic workup with a rapid screening for malnutrition using the Child-Pugh score and BMI, and in selected patients the RHF-NPT to stage patients in low, medium and high risk and conducting a detailed nutritional assessment including assessment of complications of malnutrition 
in patients at medium and high risk should be implemented in every center. Education on malnutrition in cirrhosis for all health care professionals who treat patients with liver cirrhosis and the availability of trained dieticians seem crucial in the future management process of malnutrition in cirrhosis, to account for the complexity of the disease and the need for individualized management. From a pathophysiological point of view, more work is needed to identify the drivers of malnutrition, especially considering the complex interplay between the gut microbiome and nutrient metabolism. Therapeutic efforts should consider alternative pathophysiological mechanisms in the development of malnutrition such as the role of inflammation and dysbiosis to identify potential therapeutic targets beyond the pure increase of nutritional intake. Further clinical studies, ideally as multicenter, multidisciplinary initiatives are needed to diagnose and adequately treat malnutrition in cirrhosis.

Supplementary Materials: The following are available online at https:/ / www.mdpi.com/2072-664 3/13/2/540/s1.

Author Contributions: Conceptualization, V.S.; writing-original draft preparation, V.S., J.T., L.R., B.A.; writing—review and editing, V.S., J.T., L.R., B.A.; visualization, J.T., L.R.; supervision, V.S. All authors have read and agreed to the published version of the manuscript.

Funding: This research was funded by a grant from the Austrian Science Fund (FWF) KLI 741 to VS.

Institutional Review Board Statement: Not applicable.

Informed Consent Statement: Not applicable.

Data Availability Statement: Not applicable.

Conflicts of Interest: The authors declare no conflict of interest.

\section{References}

1. Pimpin, L.; On Behalf of the HEPAHEALTH Steering Committee. HEPAHEALTH Project Report; Europeal Association for the Study of the Liver: Geneva, Switzerland, 2018.

2. Tapper, E.B.; Parikh, N.D. Mortality due to cirrhosis and liver cancer in the United States, 1999-2016: Observational study. BMJ 2018, 362, k2817. [CrossRef]

3. Gundling, F.; Seidl, H.; Pehl, C.; Schmidt, T.; Schepp, W. How close do gastroenterologists follow specific guidelines for nutrition recommendations in liver cirrhosis? A survey of current practice. Eur. J. Gastroenterol. Hepatol. 2009, 21, 756-761. [CrossRef]

4. Patel, A.; Silverman, S.; Baghdadi, J.; Shah, O.; Sundaram, V. Osteoporotic Fracture Risk and Health Care Burden in Patients with Cirrhosis. J. Clin. Gastroenterol. 2019, 53, 543-548. [CrossRef]

5. Sam, J.; Nguyen, G.C. Protein-calorie malnutrition as a prognostic indicator of mortality among patients hospitalized with cirrhosis and portal hypertension. Liver Int. 2009, 29, 1396-1402. [CrossRef] [PubMed]

6. Chaudhry, A.; Toori, K.U.; Shaikh, J.I. To determine correlation between biochemical parameters of nutritional status with disease severity in HCV related liver cirrhosis. Pak. J. Med. Sci. 2018, 34, 154-158. [CrossRef] [PubMed]

7. Naqvi, I.H.; Mahmood, K.; Salekeen, S.; Akhter, S.T. Determining the frequency and severity of malnutrition and correlating it with the severity of liver cirrhosis. Turk. J. Gastroenterol. 2013, 24, 415-422. [CrossRef]

8. Atiemo, K.; Skaro, A.; Maddur, H.; Zhao, L.; Montag, S.; VanWagner, L.; Goel, S.; Kho, A.; Ho, B.; Kang, R.; et al. Mortality Risk Factors among Patients with Cirrhosis and a Low Model for End-Stage Liver Disease Sodium Score ( $\leq 15)$ : An Analysis of Liver Transplant Allocation Policy Using Aggregated Electronic Health Record Data. Am. J. Transplant. 2017, 17, 2410-2419. [CrossRef]

9. Bruch, J.P.; Alvares, D.A.S.M.R.; Alves, B.C.; Dall'alba, V. Reduced Hand Grip Strength in Overweight and Obese Chronic Hepatitis C Patients. Arq. Gastroenterol. 2016, 53, 31-35. [CrossRef]

10. Bunchorntavakul, C.; Supanun, R.; Atsawarungruangkit, A. Nutritional Status and its Impact on Clinical Outcomes for Patients Admitted to Hospital with Cirrhosis. J. Med. Assoc. Thai. 2016, 99 (Suppl. 2), S47-S55.

11. Maharshi, S.; Sharma, B.C.; Srivastava, S. Malnutrition in cirrhosis increases morbidity and mortality. J. Gastroenterol. Hepatol. 2015, 30, 1507-1513. [CrossRef]

12. Ribeiro, H.S.; Mauricio, S.F.; Antonio da Silva, T.; de Vasconcelos Generoso, S.; Lima, A.S.; Toulson Davisson Correia, M.I. Combined nutritional assessment methods to predict clinical outcomes in patients on the waiting list for liver transplantation. Nutrition 2018, 47, 21-26. [CrossRef]

13. Huisman, E.J.; Trip, E.J.; Siersema, P.D.; van Hoek, B.; van Erpecum, K.J. Protein energy malnutrition predicts complications in liver cirrhosis. Eur. J. Gastroenterol. Hepatol. 2011, 23, 982-989. [CrossRef] [PubMed] 
14. Ruiz-Margain, A.; Macias-Rodriguez, R.U.; Ampuero, J.; Cubero, F.J.; Chi-Cervera, L.; Rios-Torres, S.L.; Duarte-Rojo, A.; EspinosaCuevas, A.; Romero-Gomez, M.; Torre, A. Low phase angle is associated with the development of hepatic encephalopathy in patients with cirrhosis. World J. Gastroenterol. 2016, 22, 10064-10070. [CrossRef]

15. Lindqvist, C.; Majeed, A.; Wahlin, S. Body composition assessed by dual-energy X-ray absorptiometry predicts early infectious complications after liver transplantation. J. Hum. Nutr. Diet 2017, 30, 284-291. [CrossRef]

16. Bering, T.; Diniz, K.G.D.; Coelho, M.P.P.; Vieira, D.A.; Soares, M.M.S.; Kakehasi, A.M.; Correia, M.; Teixeira, R.; Queiroz, D.M.M.; Rocha, G.A.; et al. Association between pre-sarcopenia, sarcopenia, and bone mineral density in patients with chronic hepatitis C. J. Cachexia Sarcopenia Muscle 2018, 9, 255-268. [CrossRef]

17. Carey, E.J.; Lai, J.C.; Wang, C.W.; Dasarathy, S.; Lobach, I.; Montano-Loza, A.J.; Dunn, M.A.; Fitness, L.E.; Exercise in Liver Transplantation, C. A multicenter study to define sarcopenia in patients with end-stage liver disease. Liver Transplant. 2017, 23, 625-633. [CrossRef]

18. Chang, K.V.; Chen, J.D.; Wu, W.T.; Huang, K.C.; Lin, H.Y.; Han, D.S. Is sarcopenia associated with hepatic encephalopathy in liver cirrhosis? A systematic review and meta-analysis. J. Formos. Med. Assoc. 2019, 118, 833-842. [CrossRef]

19. Chinnaratha, M.A.; Chaudhary, S.; Doogue, M.; McCormick, R.J.; Woodman, R.J.; Wigg, A.J. Prevalence of hepatic osteodystrophy and vitamin D deficiency in cirrhosis. Intern. Med. J. 2015, 45, 1230-1235. [CrossRef] [PubMed]

20. Hanai, T.; Shiraki, M.; Nishimura, K.; Ohnishi, S.; Imai, K.; Suetsugu, A.; Takai, K.; Shimizu, M.; Moriwaki, H. Sarcopenia impairs prognosis of patients with liver cirrhosis. Nutrition 2015, 31, 193-199. [CrossRef]

21. Hara, N.; Iwasa, M.; Sugimoto, R.; Mifuji-Moroka, R.; Yoshikawa, K.; Terasaka, E.; Hattori, A.; Ishidome, M.; Kobayashi, Y.; Hasegawa, H.; et al. Sarcopenia and Sarcopenic Obesity Are Prognostic Factors for Overall Survival in Patients with Cirrhosis. Intern. Med. 2016, 55, 863-870. [CrossRef]

22. Kalafateli, M.; Mantzoukis, K.; Choi Yau, Y.; Mohammad, A.O.; Arora, S.; Rodrigues, S.; de Vos, M.; Papadimitriou, K.; Thorburn, D.; O'Beirne, J.; et al. Malnutrition and sarcopenia predict post-liver transplantation outcomes independently of the Model for End-stage Liver Disease score. J. Cachexia Sarcopenia Muscle 2017, 8, 113-121. [CrossRef]

23. Lai, J.C.; Covinsky, K.E.; Dodge, J.L.; Boscardin, W.J.; Segev, D.L.; Roberts, J.P.; Feng, S. Development of a novel frailty index to predict mortality in patients with end-stage liver disease. Hepatology 2017, 66, 564-574. [CrossRef]

24. Lai, J.C.; Dodge, J.L.; McCulloch, C.E.; Covinsky, K.E.; Singer, J.P. Frailty and the Burden of Concurrent and Incident Disability in Patients With Cirrhosis: A Prospective Cohort Study. Hepatol. Commun. 2020, 4, 126-133. [CrossRef]

25. Lai, J.C.; Rahimi, R.S.; Verna, E.C.; Kappus, M.R.; Dunn, M.A.; McAdams-DeMarco, M.; Haugen, C.E.; Volk, M.L.; Duarte-Rojo, A.; Ganger, D.R.; et al. Frailty Associated With Waitlist Mortality Independent of Ascites and Hepatic Encephalopathy in a Multicenter Study. Gastroenterology 2019, 156, 1675-1682. [CrossRef]

26. Bunchorntavakul, C.; Reddy, K.R. Review article: Malnutrition/sarcopenia and frailty in patients with cirrhosis. Aliment. Pharmacol. Ther. 2020, 51, 64-77. [CrossRef]

27. Iwasa, M.; Iwata, K.; Hara, N.; Hattori, A.; Ishidome, M.; Sekoguchi-Fujikawa, N.; Mifuji-Moroka, R.; Sugimoto, R.; Fujita, N.; Kobayashi, Y.; et al. Nutrition therapy using a multidisciplinary team improves survival rates in patients with liver cirrhosis. Nutrition 2013, 29, 1418-1421. [CrossRef]

28. Reuter, B.; Shaw, J.; Hanson, J.; Tate, V.; Acharya, C.; Bajaj, J.S. Nutritional Assessment in Inpatients With Cirrhosis Can Be Improved After Training and Is Associated With Lower Readmissions. Liver Transplant. 2019, 25, 1790-1799. [CrossRef]

29. Ferreira, L.G.; Ferreira Martins, A.I.; Cunha, C.E.; Anastacio, L.R.; Lima, A.S.; Correia, M.I. Negative energy balance secondary to inadequate dietary intake of patients on the waiting list for liver transplantation. Nutrition 2013, 29, 1252-1258. [CrossRef]

30. Ferreira, L.G.; Anastacio, L.R.; Lima, A.S.; Correia, M.I. Malnutrition and inadequate food intake of patients in the waiting list for liver transplant. Rev. Assoc. Med. Bras. 2009, 55, 389-393. [CrossRef]

31. Marchesini, G.; Bianchi, G.; Lucidi, P.; Villanova, N.; Zoli, M.; De Feo, P. Plasma ghrelin concentrations, food intake, and anorexia in liver failure. J. Clin. Endocrinol. Metab. 2004, 89, 2136-2141. [CrossRef]

32. Nielsen, K.; Kondrup, J.; Martinsen, L.; Stilling, B.; Wikman, B. Nutritional assessment and adequacy of dietary intake in hospitalized patients with alcoholic liver cirrhosis. Br. J. Nutr. 1993, 69, 665-679. [CrossRef] [PubMed]

33. Ney, M.; Abraldes, J.G.; Ma, M.; Belland, D.; Harvey, A.; Robbins, S.; Den Heyer, V.; Tandon, P. Insufficient Protein Intake Is Associated With Increased Mortality in 630 Patients With Cirrhosis Awaiting Liver Transplantation. Nutr. Clin. Pract. 2015, 30, 530-536. [CrossRef]

34. Ney, M.; Gramlich, L.; Mathiesen, V.; Bailey, R.J.; Haykowsky, M.; Ma, M.; Abraldes, J.G.; Tandon, P. Patient-perceived barriers to lifestyle interventions in cirrhosis. Saudi J. Gastroenterol. 2017, 23, 97-104. [CrossRef]

35. Pashayee-Khamene, F.; Saber-Firoozi, M.; Hatami, B.; Rashidkhani, B.; Aghamohammadi, V.; Mohammadi, E.; Hekmatdoost, A. Food groups intake of cirrhotic patients, comparison with the nutritional status and disease stage. Gastroenterol. Hepatol. Bed Bench 2019, 12, 226-232.

36. Izbeki, F.; Kiss, I.; Wittmann, T.; Varkonyi, T.T.; Legrady, P.; Lonovics, J. Impaired accommodation of proximal stomach in patients with alcoholic liver cirrhosis. Scand. J. Gastroenterol. 2002, 37, 1403-1410. [CrossRef]

37. Aprile, L.R.; Meneghelli, U.G.; Martinelli, A.L.; Monteiro, C.R. Gastric motility in patients with presinusoidal portal hypertension. Am. J. Gastroenterol. 2002, 97, 3038-3044. [CrossRef]

38. Aqel, B.A.; Scolapio, J.S.; Dickson, R.C.; Burton, D.D.; Bouras, E.P. Contribution of ascites to impaired gastric function and nutritional intake in patients with cirrhosis and ascites. Clin. Gastroenterol. Hepatol. 2005, 3, 1095-1100. [CrossRef] 
39. Grungreiff, K.; Reinhold, D.; Wedemeyer, H. The role of zinc in liver cirrhosis. Ann. Hepatol. 2016, 15, 7-16. [CrossRef] [PubMed]

40. Madden, A.M.; Bradbury, W.; Morgan, M.Y. Taste perception in cirrhosis: Its relationship to circulating micronutrients and food preferences. Hepatology 1997, 26, 40-48. [CrossRef]

41. Gu, X.B.; Yang, X.J.; Zhu, H.Y.; Xu, B.Y. Effect of a diet with unrestricted sodium on ascites in patients with hepatic cirrhosis. Gut Liver 2012, 6, 355-361. [CrossRef] [PubMed]

42. Haberl, J.; Zollner, G.; Fickert, P.; Stadlbauer, V. To salt or not to salt?-That is the question in cirrhosis. Liver Int. 2018, 38, 1148-1159. [CrossRef]

43. Howick, K.; Griffin, B.T.; Cryan, J.F.; Schellekens, H. From Belly to Brain: Targeting the Ghrelin Receptor in Appetite and Food Intake Regulation. Int. J. Mol. Sci. 2017, 18, 273. [CrossRef]

44. El-Shehaby, A.M.; Obaia, E.M.; Alwakil, S.S.; Hiekal, A.A. Total and acylated ghrelin in liver cirrhosis: Correlation with clinical and nutritional status. Scand. J. Clin. Lab. Investig. 2010, 70, 252-258. [CrossRef]

45. Romiti, A.; Merli, M.; Martorano, M.; Parrilli, G.; Martino, F.; Riggio, O.; Truscelli, A.; Capocaccia, L.; Budillon, G. Malabsorption and nutritional abnormalities in patients with liver cirrhosis. Ital. J. Gastroenterol. 1990, 22, 118-123. [PubMed]

46. Linscheer, W.G.; Patterson, J.F.; Moore, E.W.; Clermont, R.J.; Robins, S.J.; Chalmers, T.C. Medium and long chain fat absorption in patients with cirrhosis. J. Clin. Investig. 1966, 45, 1317-1325. [CrossRef]

47. Lanspa, S.J.; Chan, A.T.; Bell, J.S., 3rd; Go, V.L.; Dickson, E.R.; DiMagno, E.P. Pathogenesis of steatorrhea in primary biliary cirrhosis. Hepatology 1985, 5, 837-842. [CrossRef] [PubMed]

48. Hofmann, A.F. The continuing importance of bile acids in liver and intestinal disease. Arch. Intern. Med. 1999, 159, 2647-2658. [CrossRef] [PubMed]

49. Maslennikov, R.; Pavlov, C.; Ivashkin, V. Small intestinal bacterial overgrowth in cirrhosis: Systematic review and meta-analysis. Hepatol. Int. 2018, 12, 567-576. [CrossRef]

50. Shindo, K.; Machida, M.; Miyakawa, K.; Fukumura, M. A syndrome of cirrhosis, achlorhydria, small intestinal bacterial overgrowth, and fat malabsorption. Am. J. Gastroenterol. 1993, 88, 2084-2091. [PubMed]

51. Li, B.R.; Pan, J.; Du, T.T.; Liao, Z.; Ye, B.; Zou, W.B.; Chen, H.; Ji, J.T.; Zheng, Z.H.; Wang, D.; et al. Risk Factors for Steatorrhea in Chronic Pancreatitis: A Cohort of 2,153 Patients. Sci. Rep. 2016, 6, 21381. [CrossRef]

52. Dumasy, V.; Delhaye, M.; Cotton, F.; Deviere, J. Fat malabsorption screening in chronic pancreatitis. Am. J. Gastroenterol. 2004, 99, 1350-1354. [CrossRef] [PubMed]

53. Davcev, P.; Vanovski, B.; Sestakov, D.; Tadzer, I. Protein-losing enteropathy in patients with liver cirrhosis. Digestion 1969, 2, 17-22. [CrossRef]

54. Dahlqvist, G.E.; Jamar, F.; Zech, F.; Geubel, A.P. In-111 transferrin scintigraphy in cirrhosis with hypoalbuminemia: Evidence for protein-losing enteropathy in a small group of selected cases. Scand. J. Gastroenterol. 2012, 47, 1247-1252. [CrossRef] [PubMed]

55. Takada, A.; Kobayashi, K.; Takeuchi, J. Gastroenteric clearance of albumin in liver icrrhosis; relative protein-losing gastroenteropathy. Digestion 1970, 3, 154-164. [CrossRef]

56. Nikaki, K.; Gupte, G.L. Assessment of intestinal malabsorption. Best Pract. Res. Clin. Gastroenterol. 2016, 30, 225-235. [CrossRef]

57. Suter, P.M.; Schutz, Y.; Jequier, E. The effect of ethanol on fat storage in healthy subjects. N. Engl. J. Med. 1992, 326, 983-987. [CrossRef] [PubMed]

58. Sonko, B.J.; Prentice, A.M.; Murgatroyd, P.R.; Goldberg, G.R.; van de Ven, M.L.; Coward, W.A. Effect of alcohol on postmeal fat storage. Am. J. Clin. Nutr. 1994, 59, 619-625. [CrossRef] [PubMed]

59. Ontko, J.A. Effects of ethanol on the metabolism of free fatty acids in isolated liver cells. J. Lipid Res. 1973, 14, 78-86. [CrossRef]

60. Siler, S.Q.; Neese, R.A.; Hellerstein, M.K. De novo lipogenesis, lipid kinetics, and whole-body lipid balances in humans after acute alcohol consumption. Am. J. Clin. Nutr. 1999, 70, 928-936. [CrossRef]

61. You, M.; Fischer, M.; Deeg, M.A.; Crabb, D.W. Ethanol induces fatty acid synthesis pathways by activation of sterol regulatory element-binding protein (SREBP). J. Biol. Chem. 2002, 277, 29342-29347. [CrossRef] [PubMed]

62. Correnti, J.M.; Gottshall, L.; Lin, A.; Williams, B.; Oranu, A.; Beck, J.; Chen, J.; Bennett, M.J.; Carr, R.M. Ethanol and C2 ceramide activate fatty acid oxidation in human hepatoma cells. Sci. Rep. 2018, 8, 12923. [CrossRef]

63. Cederbaum, A.I.; Lieber, C.S.; Beattie, D.S.; Rubin, E. Effect of chronic ethanol ingestion on fatty acid oxidation by hepatic mitochondria. J. Biol. Chem. 1975, 250, 5122-5129. [CrossRef]

64. Blomstrand, R.; Kager, L.; Lantto, O. Studies on the ethanol-induced decrease of fatty acid oxidation in rat and human liver slices. Life Sci. 1973, 13, 1131-1141. [CrossRef]

65. Fabbrini, E.; Mohammed, B.S.; Magkos, F.; Korenblat, K.M.; Patterson, B.W.; Klein, S. Alterations in adipose tissue and hepatic lipid kinetics in obese men and women with nonalcoholic fatty liver disease. Gastroenterology 2008, 134, 424-431. [CrossRef]

66. Changani, K.K.; Jalan, R.; Cox, I.J.; Ala-Korpela, M.; Bhakoo, K.; Taylor-Robinson, S.D.; Bell, J.D. Evidence for altered hepatic gluconeogenesis in patients with cirrhosis using in vivo 31-phosphorus magnetic resonance spectroscopy. Gut 2001, 49, 557-564. [CrossRef] [PubMed]

67. Kinny-Koster, B.; Bartels, M.; Becker, S.; Scholz, M.; Thiery, J.; Ceglarek, U.; Kaiser, T. Plasma Amino Acid Concentrations Predict Mortality in Patients with End-Stage Liver Disease. PLoS ONE 2016, 11, e0159205. [CrossRef]

68. McCullough, A.J.; Mullen, K.D.; Kalhan, S.C. Body cell mass and leucine metabolism in cirrhosis. Gastroenterology 1992, 102, 1325-1333. [CrossRef] 
69. Morgan, M.Y.; Marshall, A.W.; Milsom, J.P.; Sherlock, S. Plasma amino-acid patterns in liver disease. Gut 1982, 23, 362-370. [CrossRef]

70. Record, C.O.; Buxton, B.; Chase, R.A.; Curzon, G.; Murray-Lyon, I.M.; Williams, R. Plasma and brain amino acids in fulminant hepatic failure and their relationship to hepatic encephalopathy. Eur. J. Clin. Investig. 1976, 6, 387-394. [CrossRef] [PubMed]

71. Collins, J.R.; Lacy, W.W.; Stiel, J.N.; Crofford, O.B. Glucose intolerance and insulin resistance in patients with liver disease. II. A study of etiologic factors and evaluation of insulin actions. Arch. Intern. Med. 1970, 126, 608-614. [CrossRef] [PubMed]

72. Muller, M.J.; Bottcher, J.; Selberg, O.; Weselmann, S.; Boker, K.H.; Schwarze, M.; von zur Muhlen, A.; Manns, M.P. Hypermetabolism in clinically stable patients with liver cirrhosis. Am. J. Clin. Nutr. 1999, 69, 1194-1201. [CrossRef] [PubMed]

73. Nakaya, Y.; Harada, N.; Kakui, S.; Okada, K.; Takahashi, A.; Inoi, J.; Ito, S. Severe catabolic state after prolonged fasting in cirrhotic patients: Effect of oral branched-chain amino-acid-enriched nutrient mixture. J. Gastroenterol. 2002, 37, 531-536. [CrossRef] [PubMed]

74. Owen, O.E.; Reichle, F.A.; Mozzoli, M.A.; Kreulen, T.; Patel, M.S.; Elfenbein, I.B.; Golsorkhi, M.; Chang, K.H.; Rao, N.S.; Sue, H.S.; et al. Hepatic, gut, and renal substrate flux rates in patients with hepatic cirrhosis. J. Clin. Investig. 1981, 68, 240-252. [CrossRef]

75. Petersen, K.F.; Krssak, M.; Navarro, V.; Chandramouli, V.; Hundal, R.; Schumann, W.C.; Landau, B.R.; Shulman, G.I. Contributions of net hepatic glycogenolysis and gluconeogenesis to glucose production in cirrhosis. Am. J. Physiol. 1999, 276, E529-E535. [CrossRef]

76. Yeung, R.T.; Wang, C.C. A study of carbohydrate metabolism in postnecrotic cirrhosis liver. Gut 1974, 15, 907-912. [CrossRef]

77. Dasarathy, J.; Alkhouri, N.; Dasarathy, S. Changes in body composition after transjugular intrahepatic portosystemic stent in cirrhosis: A critical review of literature. Liver Int. 2011, 31, 1250-1258. [CrossRef]

78. Holland-Fischer, P.; Vilstrup, H.; Frystyk, J.; Nielsen, D.T.; Flyvbjerg, A.; Gronbaek, H. The IGF system after insertion of a transjugular intrahepatic porto-systemic shunt in patients with liver cirrhosis. Eur. J. Endocrinol. 2009, 160, 957-963. [CrossRef] [PubMed]

79. Plauth, M.; Schutz, T.; Buckendahl, D.P.; Kreymann, G.; Pirlich, M.; Grungreiff, S.; Romaniuk, P.; Ertl, S.; Weiss, M.L.; Lochs, $\mathrm{H}$. Weight gain after transjugular intrahepatic portosystemic shunt is associated with improvement in body composition in malnourished patients with cirrhosis and hypermetabolism. J. Hepatol. 2004, 40, 228-233. [CrossRef]

80. Rosemurgy, A.S.; Zervos, E.E.; Goode, S.E.; Black, T.J.; Zwiebel, B.R. Differential effects on portal and effective hepatic blood flow. A comparison between transjugular intrahepatic portasystemic shunt and small-diameter H-graft portacaval shunt. Ann. Surg. 1997, 225, 601-607; discussion 607-608. [CrossRef] [PubMed]

81. Agarwal, A.; Avarebeel, S.; Choudhary, N.S.; Goudar, M.; Tejaswini, C.J. Correlation of Trace Elements in Patients of Chronic Liver Disease with Respect to Child- Turcotte- Pugh Scoring System. J. Clin. Diagn. Res. 2017, 11, OC25-OC28. [CrossRef]

82. Loguercio, C.; De Girolamo, V.; Federico, A.; Feng, S.L.; Crafa, E.; Cataldi, V.; Gialanella, G.; Moro, R.; Del Vecchio Blanco, C. Relationship of blood trace elements to liver damage, nutritional status, and oxidative stress in chronic nonalcoholic liver disease. Biol. Trace Elem. Res. 2001, 81, 245-254. [CrossRef]

83. Yoshida, Y.; Higashi, T.; Nouso, K.; Nakatsukasa, H.; Nakamura, S.I.; Watanabe, A.; Tsuji, T. Effects of zinc deficiency/zinc supplementation on ammonia metabolism in patients with decompensated liver cirrhosis. Acta Med. Okayama 2001, 55, 349-355. [CrossRef]

84. Solis-Herruzo, J.; De Cuenca, B.; Munoz-Rivero, M.C. Intestinal zinc absorption in cirrhotic patients. Z. Gastroenterol. 1989, 27, 335-338. [PubMed]

85. Pasqualetti, P.; Casale, R.; Colantonio, D.; Di Lauro, G.; Festuccia, V.; Natali, L.; Natali, G. Serum levels of magnesium in hepatic cirrhosis. Quad. Sclavo Diagn. 1987, 23, 12-17. [PubMed]

86. Nangliya, V.; Sharma, A.; Yadav, D.; Sunder, S.; Nijhawan, S.; Mishra, S. Study of trace elements in liver cirrhosis patients and their role in prognosis of disease. Biol. Trace Elem. Res. 2015, 165, 35-40. [CrossRef]

87. Buyukasik, N.S.; Nadir, I.; Akin, F.E.; Cakal, B.; Kav, T.; Ersoy, O.; Buyukasik, Y. Serum iron parameters in cirrhosis and chronic hepatitis: Detailed description. Turk. J. Gastroenterol. 2011, 22, 606-611. [CrossRef] [PubMed]

88. Jurczyk, K.; Wawrzynowicz-Syczewska, M.; Boron-Kaczmarska, A.; Sych, Z. Serum iron parameters in patients with alcoholic and chronic cirrhosis and hepatitis. Med. Sci. Monit. 2001, 7, 962-965. [PubMed]

89. Rahelic, D.; Kujundzic, M.; Romic, Z.; Brkic, K.; Petrovecki, M. Serum concentration of zinc, copper, manganese and magnesium in patients with liver cirrhosis. Coll. Antropol. 2006, 30, 523-528.

90. Teriaky, A.; Mosli, M.; Chandok, N.; Al-Judaibi, B.; Marotta, P.; Qumosani, K. Prevalence of fat-soluble vitamin (A, D, and E) and zinc deficiency in patients with cirrhosis being assessed for liver transplantation. Acta Gastroenterol. Belg. 2017, 80, 237-241.

91. Chen, W.; Chen, G. The Roles of Vitamin A in the Regulation of Carbohydrate, Lipid, and Protein Metabolism. J. Clin. Med. 2014, 3, 453-479. [CrossRef] [PubMed]

92. Saeed, A.; Hoekstra, M.; Hoeke, M.O.; Heegsma, J.; Faber, K.N. The interrelationship between bile acid and vitamin A homeostasis. Biochim. Biophys. Acta Mol. Cell Biol. Lipids 2017, 1862, 496-512. [CrossRef]

93. Kaplan, M.M.; Elta, G.H.; Furie, B.; Sadowski, J.A.; Russell, R.M. Fat-soluble vitamin nutriture in primary biliary cirrhosis. Gastroenterology 1988, 95, 787-792. [CrossRef]

94. Garrett-Laster, M.; Russell, R.M.; Jacques, P.F. Impairment of taste and olfaction in patients with cirrhosis: The role of vitamin A. Hum. Nutr. Clin. Nutr. 1984, 38, 203-214. 
95. Paternostro, R.; Wagner, D.; Reiberger, T.; Mandorfer, M.; Schwarzer, R.; Ferlitsch, M.; Trauner, M.; Peck-Radosavljevic, M.; Ferlitsch, A. Low 25-OH-vitamin D levels reflect hepatic dysfunction and are associated with mortality in patients with liver cirrhosis. Wien. Klin. Wochenschr. 2017, 129, 8-15. [CrossRef] [PubMed]

96. Stokes, C.S.; Krawczyk, M.; Reichel, C.; Lammert, F.; Grunhage, F. Vitamin D deficiency is associated with mortality in patients with advanced liver cirrhosis. Eur. J. Clin. Investig. 2014, 44, 176-183. [CrossRef]

97. Finkelmeier, F.; Kronenberger, B.; Koberle, V.; Bojunga, J.; Zeuzem, S.; Trojan, J.; Piiper, A.; Waidmann, O. Severe 25hydroxyvitamin D deficiency identifies a poor prognosis in patients with hepatocellular carcinoma-A prospective cohort study. Aliment. Pharmacol. Ther. 2014, 39, 1204-1212. [CrossRef]

98. Peres, W.A.; Chaves, G.V.; Goncalves, J.C.; Ramalho, A.; Coelho, H.S. Vitamin A deficiency in patients with hepatitis C virusrelated chronic liver disease. Br. J. Nutr. 2011, 106, 1724-1731. [CrossRef]

99. Zhou, Y.J.; Liang, M.Y.; Zhang, X.Q. Changes in serum folic acid and vitamin B12 levels in liver cirrhosis and its clinical significance. Zhonghua Nei Ke Za Zhi 1992, 30, 625-627, 658.

100. Majumdar, S.K.; Shaw, G.K.; O'Gorman, P.; Aps, E.J.; Offerman, E.L.; Thomson, A.D. Blood vitamin status (B1, B2, B6, folic acid and B12) in patients with alcoholic liver disease. Int. J. Vitam. Nutr. Res. 1982, 52, 266-271. [PubMed]

101. Beattie, A.D.; Sherlock, S. Ascorbic acid deficiency in liver disease. Gut 1976, 17, 571-575. [CrossRef]

102. Sugihara, T.; Koda, M.; Okamoto, T.; Miyoshi, K.; Matono, T.; Oyama, K.; Hosho, K.; Okano, J.I.; Isomoto, H.; Murawaki, Y. Falsely Elevated Serum Vitamin B12 Levels Were Associated with the Severity and Prognosis of Chronic Viral Liver Disease. Yonago Acta Med. 2017, 60, 31-39.

103. Areekul, S.; Panatampon, P.; Doungbarn, J. Vitamin B12 and vitamin B12 binding proteins in liver diseases. Southeast. Asian J. Trop. Med. Public Health 1977, 8, 322-328. [PubMed]

104. Prieto-Frias, C.; Conchillo, M.; Payeras, M.; Inarrairaegui, M.; Davola, D.; Fruhbeck, G.; Salvador, J.; Rodriguez, M.; Richter, J.A.; Mugueta, C.; et al. Factors related to increased resting energy expenditure in men with liver cirrhosis. Eur. J. Gastroenterol. Hepatol. 2016, 28, 139-145. [CrossRef] [PubMed]

105. Peng, S.; Plank, L.D.; McCall, J.L.; Gillanders, L.K.; Mcllroy, K.; Gane, E.J. Body composition, muscle function, and energy expenditure in patients with liver cirrhosis: A comprehensive study. Am. J. Clin. Nutr. 2007, 85, 1257-1266. [CrossRef]

106. Guglielmi, F.W.; Panella, C.; Buda, A.; Budillon, G.; Caregaro, L.; Clerici, C.; Conte, D.; Federico, A.; Gasbarrini, G.; Guglielmi, A.; et al. Nutritional state and energy balance in cirrhotic patients with or without hypermetabolism. Multicentre prospective study by the 'Nutritional Problems in Gastroenterology' Section of the Italian Society of Gastroenterology (SIGE). Dig. Liver Dis. 2005, 37, 681-688. [CrossRef]

107. Greco, A.V.; Mingrone, G.; Benedetti, G.; Capristo, E.; Tataranni, P.A.; Gasbarrini, G. Daily energy and substrate metabolism in patients with cirrhosis. Hepatology 1998, 27, 346-350. [CrossRef] [PubMed]

108. Mathur, S.; Peng, S.; Gane, E.J.; McCall, J.L.; Plank, L.D. Hypermetabolism predicts reduced transplant-free survival independent of MELD and Child-Pugh scores in liver cirrhosis. Nutrition 2007, 23, 398-403. [CrossRef]

109. Tajika, M.; Kato, M.; Mohri, H.; Miwa, Y.; Kato, T.; Ohnishi, H.; Moriwaki, H. Prognostic value of energy metabolism in patients with viral liver cirrhosis. Nutrition 2002, 18, 229-234. [CrossRef]

110. Selberg, O.; Bottcher, J.; Tusch, G.; Pichlmayr, R.; Henkel, E.; Muller, M.J. Identification of high- and low-risk patients before liver transplantation: A prospective cohort study of nutritional and metabolic parameters in 150 patients. Hepatology 1997, 25, 652-657. [CrossRef]

111. Roubenoff, R.; Roubenoff, R.A.; Cannon, J.G.; Kehayias, J.J.; Zhuang, H.; Dawson-Hughes, B.; Dinarello, C.A.; Rosenberg, I.H. Rheumatoid cachexia: Cytokine-driven hypermetabolism accompanying reduced body cell mass in chronic inflammation. J. Clin. Investig. 1994, 93, 2379-2386. [CrossRef]

112. Tilg, H.; Wilmer, A.; Vogel, W.; Herold, M.; Nolchen, B.; Judmaier, G.; Huber, C. Serum levels of cytokines in chronic liver diseases. Gastroenterology 1992, 103, 264-274. [CrossRef]

113. Huang, Y.S.; Hwang, S.J.; Chan, C.Y.; Wu, J.C.; Chao, Y.; Chang, F.Y.; Lee, S.D. Serum levels of cytokines in hepatitis C-related liver disease: A longitudinal study. Zhonghua Yi Xue Za Zhi (Taipei) 1999, 62, 327-333.

114. Laso, F.J.; Lapena, P.; Madruga, J.I.; San Miguel, J.F.; Orfao, A.; Iglesias, M.C.; Alvarez-Mon, M. Alterations in tumor necrosis factor-alpha, interferon-gamma, and interleukin-6 production by natural killer cell-enriched peripheral blood mononuclear cells in chronic alcoholism: Relationship with liver disease and ethanol intake. Alcohol. Clin. Exp. Res. 1997, 21, 1226-1231. [CrossRef] [PubMed]

115. Muller, C.; Zielinski, C.C. Interleukin-6 production by peripheral blood monocytes in patients with chronic liver disease and acute viral hepatitis. J. Hepatol. 1992, 15, 372-377. [CrossRef]

116. Khoruts, A.; Stahnke, L.; McClain, C.J.; Logan, G.; Allen, J.I. Circulating tumor necrosis factor, interleukin-1 and interleukin-6 concentrations in chronic alcoholic patients. Hepatology 1991, 13, 267-276. [CrossRef]

117. Lin, S.Y.; Wang, Y.Y.; Sheu, W.H. Increased serum leptin concentrations correlate with soluble tumour necrosis factor receptor levels in patients with cirrhosis. Clin. Endocrinol. 2002, 57, 805-811. [CrossRef]

118. Shinsyu, A.; Bamba, S.; Kurihara, M.; Matsumoto, H.; Sonoda, A.; Inatomi, O.; Andoh, A.; Takebayashi, K.; Kojima, M.; Iida, H.; et al. Inflammatory cytokines, appetite-regulating hormones, and energy metabolism in patients with gastrointestinal cancer. Oncol. Lett. 2020, 20, 1469-1479. [CrossRef] 
119. Paulsen, O.; Laird, B.; Aass, N.; Lea, T.; Fayers, P.; Kaasa, S.; Klepstad, P. The relationship between pro-inflammatory cytokines and pain, appetite and fatigue in patients with advanced cancer. PLoS ONE 2017, 12, e0177620. [CrossRef] [PubMed]

120. Bajaj, J.S.; Kakiyama, G.; Zhao, D.; Takei, H.; Fagan, A.; Hylemon, P.; Zhou, H.; Pandak, W.M.; Nittono, H.; Fiehn, O.; et al. Continued Alcohol Misuse in Human Cirrhosis is Associated with an Impaired Gut-Liver Axis. Alcohol. Clin. Exp. Res. 2017, 41, 1857-1865. [CrossRef]

121. Chen, P.; Starkel, P.; Turner, J.R.; Ho, S.B.; Schnabl, B. Dysbiosis-induced intestinal inflammation activates tumor necrosis factor receptor I and mediates alcoholic liver disease in mice. Hepatology 2015, 61, 883-894. [CrossRef]

122. Horvath, A.; Rainer, F.; Bashir, M.; Leber, B.; Schmerboeck, B.; Klymiuk, I.; Groselj-Strele, A.; Durdevic, M.; Freedberg, D.E.; Abrams, J.A.; et al. Biomarkers for oralization during long-term proton pump inhibitor therapy predict survival in cirrhosis. Sci. Rep. 2019, 9, 12000. [CrossRef]

123. Quinones, M.; Ferno, J.; Al-Massadi, O. Ghrelin and liver disease. Rev. Endocr. Metab. Disord. 2020, 21, 45-56. [CrossRef] [PubMed]

124. Tschop, M.; Smiley, D.L.; Heiman, M.L. Ghrelin induces adiposity in rodents. Nature 2000, 407, 908-913. [CrossRef]

125. Ahima, R.S.; Prabakaran, D.; Mantzoros, C.; Qu, D.; Lowell, B.; Maratos-Flier, E.; Flier, J.S. Role of leptin in the neuroendocrine response to fasting. Nature 1996, 382, 250-252. [CrossRef]

126. Ockenga, J.; Bischoff, S.C.; Tillmann, H.L.; Rifai, K.; Widjaja, A.; Boker, K.H.; Manns, M.P.; Brabant, G. Elevated bound leptin correlates with energy expenditure in cirrhotics. Gastroenterology 2000, 119, 1656-1662. [CrossRef] [PubMed]

127. Richardson, R.A.; Davidson, H.I.; Hinds, A.; Cowan, S.; Rae, P.; Garden, O.J. Influence of the metabolic sequelae of liver cirrhosis on nutritional intake. Am. J. Clin. Nutr. 1999, 69, 331-337. [CrossRef]

128. Grossmann, M.; Hoermann, R.; Gani, L.; Chan, I.; Cheung, A.; Gow, P.J.; Li, A.; Zajac, J.D.; Angus, P. Low testosterone levels as an independent predictor of mortality in men with chronic liver disease. Clin. Endocrinol. 2012, 77, 323-328. [CrossRef] [PubMed]

129. Griggs, R.C.; Kingston, W.; Jozefowicz, R.F.; Herr, B.E.; Forbes, G.; Halliday, D. Effect of testosterone on muscle mass and muscle protein synthesis. J. Appl. Physiol. 1989, 66, 498-503. [CrossRef]

130. Stadlbauer, V.; Komarova, I.; Klymiuk, I.; Durdevic, M.; Reisinger, A.; Blesl, A.; Rainer, F.; Horvath, A. Disease severity and proton pump inhibitor use impact strongest on faecal microbiome composition in liver cirrhosis. Liver Int. 2020, 40, 866-877. [CrossRef]

131. Ticinesi, A.; Lauretani, F.; Milani, C.; Nouvenne, A.; Tana, C.; Del Rio, D.; Maggio, M.; Ventura, M.; Meschi, T. Aging Gut Microbiota at the Cross-Road between Nutrition, Physical Frailty, and Sarcopenia: Is There a Gut-Muscle Axis? Nutrients 2017, 9, 1303. [CrossRef] [PubMed]

132. de Sire, R.; Rizzatti, G.; Ingravalle, F.; Pizzoferrato, M.; Petito, V.; Lopetuso, L.; Graziani, C.; de Sire, A.; Mentella, M.C.; Mele, M.C.; et al. Skeletal muscle-gut axis: Emerging mechanisms of sarcopenia for intestinal and extra intestinal diseases. Minerva Gastroenterol. Dietol. 2018, 64, 351-362. [CrossRef]

133. den Besten, G.; Lange, K.; Havinga, R.; van Dijk, T.H.; Gerding, A.; van Eunen, K.; Müller, M.; Groen, A.K.; Hooiveld, G.J.; Bakker, B.M.; et al. Gut-derived short-chain fatty acids are vividly assimilated into host carbohydrates and lipids. Am. J. Physiol. Gastrointest. Liver. Physiol. 2013, 305, G900-G910. [CrossRef] [PubMed]

134. Grosicki, G.J.; Fielding, R.A.; Lustgarten, M.S. Gut Microbiota Contribute to Age-Related Changes in Skeletal Muscle Size, Composition, and Function: Biological Basis for a Gut-Muscle Axis. Calcif. Tissue Int. 2018, 102, 433-442. [CrossRef] [PubMed]

135. Li, D.; Li, Y.; Dai, W.; Wang, H.; Qiu, C.; Feng, S.; Zhou, Q.; Wang, W.; Feng, X.; Yao, K.; et al. Intestinal Bacteroides sp. Imbalance Associated With the Occurrence of Childhood Undernutrition in China. Front. Microbiol. 2019, 10, 2635. [CrossRef] [PubMed]

136. Monira, S.; Nakamura, S.; Gotoh, K.; Izutsu, K.; Watanabe, H.; Alam, N.H.; Endtz, H.P.; Cravioto, A.; Ali, S.I.; Nakaya, T.; et al. Gut microbiota of healthy and malnourished children in bangladesh. Front. Microbiol. 2011, 2, 228. [CrossRef] [PubMed]

137. Qin, N.; Yang, F.; Li, A.; Prifti, E.; Chen, Y.; Shao, L.; Guo, J.; Le Chatelier, E.; Yao, J.; Wu, L.; et al. Alterations of the human gut microbiome in liver cirrhosis. Nature 2014, 513, 59-64. [CrossRef]

138. Meyer, F.; Bannert, K.; Wiese, M.; Esau, S.; Sautter, L.F.; Ehlers, L.; Aghdassi, A.A.; Metges, C.C.; Garbe, L.-A.; Jaster, R.; et al. Molecular Mechanism Contributing to Malnutrition and Sarcopenia in Patients with Liver Cirrhosis. Int. J. Mol. Sci. 2020, 21, 5357. [CrossRef]

139. Bajaj, J.S.; Heuman, D.M.; Hylemon, P.B.; Sanyal, A.J.; White, M.B.; Monteith, P.; Noble, N.A.; Unser, A.B.; Daita, K.; Fisher, A.R.; et al. Altered profile of human gut microbiome is associated with cirrhosis and its complications. J. Hepatol. 2014, 60, 940-947. [CrossRef]

140. Bajaj, J.S.; Hylemon, P.B.; Ridlon, J.M.; Heuman, D.M.; Daita, K.; White, M.B.; Monteith, P.; Noble, N.A.; Sikaroodi, M.; Gillevet, P.M. Colonic mucosal microbiome differs from stool microbiome in cirrhosis and hepatic encephalopathy and is linked to cognition and inflammation. Am. J. Physiol. Gastrointest. Liver Physiol. 2012, 303, G675-G685. [CrossRef]

141. Malinchoc, M.; Kamath, P.S.; Gordon, F.D.; Peine, C.J.; Rank, J.; ter Borg, P.C. A model to predict poor survival in patients undergoing transjugular intrahepatic portosystemic shunts. Hepatology 2000, 31, 864-871. [CrossRef]

142. Pugh, R.N.; Murray-Lyon, I.M.; Dawson, J.L.; Pietroni, M.C.; Williams, R. Transection of the oesophagus for bleeding oesophageal varices. Br. J. Surg. 1973, 60, 646-649. [CrossRef]

143. Garcia-Tsao, G. The Child-Turcotte Classification: From Gestalt to Sophisticated Statistics and Back. Dig. Dis. Sci. 2016, 61, 3102-3104. [CrossRef]

144. Plauth, M.; Bernal, W.; Dasarathy, S.; Merli, M.; Plank, L.D.; Schutz, T.; Bischoff, S.C. ESPEN guideline on clinical nutrition in liver disease. Clin. Nutr. 2019, 38, 485-521. [CrossRef] 
145. European Association for the Study of the Liver. EASL Clinical Practice Guidelines on nutrition in chronic liver disease. J. Hepatol. 2019, 70, 172-193. [CrossRef] [PubMed]

146. European Association for the Study of the Liver. EASL Clinical Practice Guidelines for the management of patients with decompensated cirrhosis. J. Hepatol. 2018, 69, 406-460. [CrossRef] [PubMed]

147. Borhofen, S.M.; Gerner, C.; Lehmann, J.; Fimmers, R.; Gortzen, J.; Hey, B.; Geiser, F.; Strassburg, C.P.; Trebicka, J. The Royal Free Hospital-Nutritional Prioritizing Tool Is an Independent Predictor of Deterioration of Liver Function and Survival in Cirrhosis. Dig. Dis. Sci. 2016, 61, 1735-1743. [CrossRef]

148. Traub, J.; Bergheim, I.; Horvath, A.; Stadlbauer, V. Validation of Malnutrition Screening Tools in Liver Cirrhosis. Nutrients 2020, 12, 1306. [CrossRef]

149. Buchard, B.; Boirie, Y.; Cassagnes, L.; Lamblin, G.; Coilly, A.; Abergel, A. Assessment of Malnutrition, Sarcopenia and Frailty in Patients with Cirrhosis: Which Tools Should We Use in Clinical Practice? Nutrients 2020, 12, 186. [CrossRef]

150. Tandon, P.; Raman, M.; Mourtzakis, M.; Merli, M. A practical approach to nutritional screening and assessment in cirrhosis. Hepatology 2017, 65, 1044-1057. [CrossRef]

151. Fialla, A.D.; Israelsen, M.; Hamberg, O.; Krag, A.; Gluud, L.L. Nutritional therapy in cirrhosis or alcoholic hepatitis: A systematic review and meta-analysis. Liver Int. 2015, 35, 2072-2078. [CrossRef]

152. Ney, M.; Vandermeer, B.; van Zanten, S.J.; Ma, M.M.; Gramlich, L.; Tandon, P. Meta-analysis: Oral or enteral nutritional supplementation in cirrhosis. Aliment. Pharmacol. Ther. 2013, 37, 672-679. [CrossRef] [PubMed]

153. Montano-Loza, A.J.; Meza-Junco, J.; Prado, C.M.; Lieffers, J.R.; Baracos, V.E.; Bain, V.G.; Sawyer, M.B. Muscle wasting is associated with mortality in patients with cirrhosis. Clin. Gastroenterol. Hepatol. 2012, 10, 166-173, 173.e1. [CrossRef]

154. Chang, Y.; Liu, Q.Y.; Zhang, Q.; Rong, Y.M.; Lu, C.Z.; Li, H. Role of nutritional status and nutritional support in outcome of hepatitis B virus-associated acute-on-chronic liver failure. World J. Gastroenterol. 2020, 26, 4288-4301. [CrossRef] [PubMed]

155. Bories, P.N.; Campillo, B. One-month regular oral nutrition in alcoholic cirrhotic patients. Changes of nutritional status, hepatic function and serum lipid pattern. Br. J. Nutr. 1994, 72, 937-946. [CrossRef] [PubMed]

156. Manguso, F.; D'Ambra, G.; Menchise, A.; Sollazzo, R.; D’Agostino, L. Effects of an appropriate oral diet on the nutritional status of patients with HCV-related liver cirrhosis: A prospective study. Clin. Nutr. 2005, 24, 751-759. [CrossRef]

157. Maharshi, S.; Sharma, B.C.; Sachdeva, S.; Srivastava, S.; Sharma, P. Efficacy of Nutritional Therapy for Patients With Cirrhosis and Minimal Hepatic Encephalopathy in a Randomized Trial. Clin. Gastroenterol. Hepatol. 2016, 14, 454-460.e3; quiz e433. [CrossRef]

158. Dichi, J.B.; Dichi, I.; Maio, R.; Correa, C.R.; Angeleli, A.Y.; Bicudo, M.H.; Rezende, T.A.; Burini, R.C. Whole-body protein turnover in malnourished patients with child class B and C cirrhosis on diets low to high in protein energy. Nutrition 2001, 17, 239-242. [CrossRef]

159. Swart, G.R.; van den Berg, J.W.; van Vuure, J.K.; Rietveld, T.; Wattimena, D.L.; Frenkel, M. Minimum protein requirements in liver cirrhosis determined by nitrogen balance measurements at three levels of protein intake. Clin. Nutr. 1989, 8, 329-336. [CrossRef]

160. Putadechakum, S.; Klangjareonchai, T.; Soponsaritsuk, A.; Roongpisuthipong, C. Nutritional status assessment in cirrhotic patients after protein supplementation. ISRN Gastroenterol. 2012, 2012, 690402. [CrossRef]

161. Dawson, A.M.; Sherlock, S.; Summerskill, W.H. The treatment and prognosis of hepatic coma. Lancet 1956, 271, 689-694. [CrossRef]

162. Cordoba, J.; Lopez-Hellin, J.; Planas, M.; Sabin, P.; Sanpedro, F.; Castro, F.; Esteban, R.; Guardia, J. Normal protein diet for episodic hepatic encephalopathy: Results of a randomized study. J. Hepatol. 2004, 41, 38-43. [CrossRef]

163. Kearns, P.J.; Young, H.; Garcia, G.; Blaschke, T.; O’Hanlon, G.; Rinki, M.; Sucher, K.; Gregory, P. Accelerated improvement of alcoholic liver disease with enteral nutrition. Gastroenterology 1992, 102, 200-205. [CrossRef]

164. Gheorghe, L.; Iacob, R.; Vadan, R.; Iacob, S.; Gheorghe, C. Improvement of hepatic encephalopathy using a modified high-calorie high-protein diet. Rom. J. Gastroenterol. 2005, 14, 231-238.

165. Morgan, T.R.; Moritz, T.E.; Mendenhall, C.L.; Haas, R. Protein consumption and hepatic encephalopathy in alcoholic hepatitis. VA Cooperative Study Group \#275. J. Am. Coll. Nutr. 1995, 14, 152-158. [CrossRef]

166. Plank, L.D.; Gane, E.J.; Peng, S.; Muthu, C.; Mathur, S.; Gillanders, L.; McIlroy, K.; Donaghy, A.J.; McCall, J.L. Nocturnal nutritional supplementation improves total body protein status of patients with liver cirrhosis: A randomized 12-month trial. Hepatology 2008, 48, 557-566. [CrossRef]

167. Swart, G.R.; Zillikens, M.C.; van Vuure, J.K.; van den Berg, J.W. Effect of a late evening meal on nitrogen balance in patients with cirrhosis of the liver. BMJ 1989, 299, 1202-1203. [CrossRef] [PubMed]

168. Tsien, C.D.; McCullough, A.J.; Dasarathy, S. Late evening snack: Exploiting a period of anabolic opportunity in cirrhosis. J. Gastroenterol. Hepatol. 2012, 27, 430-441. [CrossRef] [PubMed]

169. Guo, Y.J.; Tian, Z.B.; Jiang, N.; Ding, X.L.; Mao, T.; Jing, X. Effects of Late Evening Snack on Cirrhotic Patients: A Systematic Review and Meta-Analysis. Gastroenterol. Res. Pract. 2018, 2018, 9189062. [CrossRef] [PubMed]

170. Vaisman, N.; Katzman, H.; Carmiel-Haggai, M.; Lusthaus, M.; Niv, E. Breakfast improves cognitive function in cirrhotic patients with cognitive impairment. Am. J. Clin. Nutr. 2010, 92, 137-140. [CrossRef] [PubMed]

171. Verboeket-van de Venne, W.P.; Westerterp, K.R.; van Hoek, B.; Swart, G.R. Energy expenditure and substrate metabolism in patients with cirrhosis of the liver: Effects of the pattern of food intake. Gut 1995, 36, 110-116. [CrossRef]

172. Plauth, M.; Cabre, E.; Riggio, O.; Assis-Camilo, M.; Pirlich, M.; Kondrup, J.; DGEM; Ferenci, P.; Holm, E.; Vom Dahl, S.; et al. ESPEN Guidelines on Enteral Nutrition: Liver disease. Clin. Nutr. 2006, 25, 285-294. [CrossRef] [PubMed] 
173. Cabre, E.; Rodriguez-Iglesias, P.; Caballeria, J.; Quer, J.C.; Sanchez-Lombrana, J.L.; Pares, A.; Papo, M.; Planas, R.; Gassull, M.A. Short- and long-term outcome of severe alcohol-induced hepatitis treated with steroids or enteral nutrition: A multicenter randomized trial. Hepatology 2000, 32, 36-42. [CrossRef] [PubMed]

174. Baltz, J.G.; Argo, C.K.; Al-Osaimi, A.M.; Northup, P.G. Mortality after percutaneous endoscopic gastrostomy in patients with cirrhosis: A case series. Gastrointest. Endosc. 2010, 72, 1072-1075. [CrossRef]

175. Plauth, M.; Cabre, E.; Campillo, B.; Kondrup, J.; Marchesini, G.; Schutz, T.; Shenkin, A.; Wendon, J. ESPEN Guidelines on Parenteral Nutrition: Hepatology. Clin. Nutr. 2009, 28, 436-444. [CrossRef]

176. Jalan, R.; Fernandez, J.; Wiest, R.; Schnabl, B.; Moreau, R.; Angeli, P.; Stadlbauer, V.; Gustot, T.; Bernardi, M.; Canton, R.; et al. Bacterial infections in cirrhosis: A position statement based on the EASL Special Conference 2013. J. Hepatol. 2014, 60, 1310-1324. [CrossRef]

177. Cunha, L.; Happi Nono, M.; Guibert, A.L.; Nidegger, D.; Beau, P.; Beauchant, M. Effects of prolonged oral nutritional support in malnourished cirrhotic patients: Results of a pilot study. Gastroenterol. Clin. Biol. 2004, 28, 36-39. [CrossRef]

178. Norman, K.; Kirchner, H.; Freudenreich, M.; Ockenga, J.; Lochs, H.; Pirlich, M. Three month intervention with protein and energy rich supplements improve muscle function and quality of life in malnourished patients with non-neoplastic gastrointestinal disease-a randomized controlled trial. Clin. Nutr. 2008, 27, 48-56. [CrossRef] [PubMed]

179. Bjelakovic, G.; Gluud, L.L.; Nikolova, D.; Bjelakovic, M.; Nagorni, A.; Gluud, C. Meta-analysis: Antioxidant supplements for liver diseases-The Cochrane Hepato-Biliary Group. Aliment. Pharmacol. Ther. 2010, 32, 356-367. [CrossRef]

180. Shen, Y.C.; Chang, Y.H.; Fang, C.J.; Lin, Y.S. Zinc supplementation in patients with cirrhosis and hepatic encephalopathy: A systematic review and meta-analysis. Nutr. J. 2019, 18,34. [CrossRef]

181. Katayama, K.; Saito, M.; Kawaguchi, T.; Endo, R.; Sawara, K.; Nishiguchi, S.; Kato, A.; Kohgo, H.; Suzuki, K.; Sakaida, I.; et al. Effect of zinc on liver cirrhosis with hyperammonemia: A preliminary randomized, placebo-controlled double-blind trial. Nutrition 2014, 30, 1409-1414. [CrossRef]

182. Takuma, Y.; Nouso, K.; Makino, Y.; Hayashi, M.; Takahashi, H. Clinical trial: Oral zinc in hepatic encephalopathy. Aliment. Pharmacol. Ther. 2010, 32, 1080-1090. [CrossRef]

183. Bresci, G.; Parisi, G.; Banti, S. Management of hepatic encephalopathy with oral zinc supplementation: A long-term treatment. Eur. J. Med. 1993, 2, 414-416.

184. Riggio, O.; Ariosto, F.; Merli, M.; Caschera, M.; Zullo, A.; Balducci, G.; Ziparo, V.; Pedretti, G.; Fiaccadori, F.; Bottari, E.; et al. Short-term oral zinc supplementation does not improve chronic hepatic encephalopathy. Results of a double-blind crossover trial. Dig. Dis. Sci. 1991, 36, 1204-1208. [CrossRef] [PubMed]

185. Rossi, R.E.; Conte, D.; Massironi, S. Diagnosis and treatment of nutritional deficiencies in alcoholic liver disease: Overview of available evidence and open issues. Dig. Liver Dis. 2015, 47, 819-825. [CrossRef] [PubMed]

186. Somi, M.H.; Rezaeifar, P.; Ostad Rahimi, A.; Moshrefi, B. Effects of low dose zinc supplementation on biochemical markers in non-alcoholic cirrhosis: A randomized clinical trial. Arch. Iran. Med. 2012, 15, 472-476.

187. Hosui, A.; Kimura, E.; Abe, S.; Tanimoto, T.; Onishi, K.; Kusumoto, Y.; Sueyoshi, Y.; Matsumoto, K.; Hirao, M.; Yamada, T.; et al. Long-Term Zinc Supplementation Improves Liver Function and Decreases the Risk of Developing Hepatocellular Carcinoma. Nutrients 2018, 10, 1955. [CrossRef] [PubMed]

188. Matsuoka, S.; Matsumura, H.; Nakamura, H.; Oshiro, S.; Arakawa, Y.; Hayashi, J.; Sekine, N.; Nirei, K.; Yamagami, H.; Ogawa, M.; et al. Zinc supplementation improves the outcome of chronic hepatitis C and liver cirrhosis. J. Clin. Biochem. Nutr. 2009, 45, 292-303. [CrossRef]

189. Weismann, K.; Christensen, E.; Dreyer, V. Zinc supplementation in alcoholic cirrhosis. A double-blind clinical trial. Acta. Med. Scand. 1979, 205, 361-366. [CrossRef]

190. Yang, F.; Ren, H.; Gao, Y.; Zhu, Y.; Huang, W. The value of severe vitamin D deficiency in predicting the mortality risk of patients with liver cirrhosis: A meta-analysis. Clin. Res. Hepatol. Gastroenterol. 2019, 43, 722-729. [CrossRef]

191. Pilz, S.; Putz-Bankuti, C.; Gaksch, M.; Spindelboeck, W.; Haselberger, M.; Rainer, F.; Posch, A.; Kreuzer, P.; Stojakovic, T.; Stadlbauer, V.; et al. Effects of Vitamin D Supplementation on Serum 25-Hydroxyvitamin D Concentrations in Cirrhotic Patients: A Randomized Controlled Trial. Nutrients 2016, 8, 278. [CrossRef]

192. Rode, A.; Fourlanos, S.; Nicoll, A. Oral vitamin D replacement is effective in chronic liver disease. Gastroenterol. Clin. Biol. 2010, 34, 618-620. [CrossRef]

193. Bjelakovic, G.; Nikolova, D.; Bjelakovic, M.; Gluud, C. Vitamin D supplementation for chronic liver diseases in adults. Cochrane Database Syst. Rev. 2017, 11, CD011564. [CrossRef] [PubMed]

194. Kato, M.; Miwa, Y.; Tajika, M.; Hiraoka, T.; Muto, Y.; Moriwaki, H. Preferential use of branched-chain amino acids as an energy substrate in patients with liver cirrhosis. Intern. Med. 1998, 37, 429-434. [CrossRef] [PubMed]

195. Yamauchi, M.; Takeda, K.; Sakamoto, K.; Ohata, M.; Toda, G. Effect of oral branched chain amino acid supplementation in the late evening on the nutritional state of patients with liver cirrhosis. Hepatol. Res. 2001, 21, 199-204. [CrossRef]

196. Nakaya, Y.; Okita, K.; Suzuki, K.; Moriwaki, H.; Kato, A.; Miwa, Y.; Shiraishi, K.; Okuda, H.; Onji, M.; Kanazawa, H.; et al. BCAA-enriched snack improves nutritional state of cirrhosis. Nutrition 2007, 23, 113-120. [CrossRef] 
197. Muto, Y.; Sato, S.; Watanabe, A.; Moriwaki, H.; Suzuki, K.; Kato, A.; Kato, M.; Nakamura, T.; Higuchi, K.; Nishiguchi, S.; et al. Overweight and obesity increase the risk for liver cancer in patients with liver cirrhosis and long-term oral supplementation with branched-chain amino acid granules inhibits liver carcinogenesis in heavier patients with liver cirrhosis. Hepatol. Res. 2006, 35, 204-214. [CrossRef]

198. Muto, Y.; Sato, S.; Watanabe, A.; Moriwaki, H.; Suzuki, K.; Kato, A.; Kato, M.; Nakamura, T.; Higuchi, K.; Nishiguchi, S.; et al. Effects of oral branched-chain amino acid granules on event-free survival in patients with liver cirrhosis. Clin. Gastroenterol. Hepatol. 2005, 3, 705-713. [CrossRef]

199. Marchesini, G.; Bianchi, G.; Merli, M.; Amodio, P.; Panella, C.; Loguercio, C.; Rossi Fanelli, F.; Abbiati, R.; Italian, B.S.G. Nutritional supplementation with branched-chain amino acids in advanced cirrhosis: A double-blind, randomized trial. Gastroenterology 2003, 124, 1792-1801. [CrossRef]

200. Horst, D.; Grace, N.D.; Conn, H.O.; Schiff, E.; Schenker, S.; Viteri, A.; Law, D.; Atterbury, C.E. Comparison of dietary protein with an oral, branched chain-enriched amino acid supplement in chronic portal-systemic encephalopathy: A randomized controlled trial. Hepatology 1984, 4, 279-287. [CrossRef]

201. Dam, G.; Aamann, L.; Vistrup, H.; Gluud, L.L. The role of Branched Chain Amino Acids in the treatment of hepatic Encephalopathy. J. Clin. Exp. Hepatol. 2018, 8, 448-451. [CrossRef] [PubMed]

202. Les, I.; Doval, E.; Garcia-Martinez, R.; Planas, M.; Cardenas, G.; Gomez, P.; Flavia, M.; Jacas, C.; Minguez, B.; Vergara, M.; et al. Effects of branched-chain amino acids supplementation in patients with cirrhosis and a previous episode of hepatic encephalopathy: A randomized study. Am. J. Gastroenterol. 2011, 106, 1081-1088. [CrossRef] [PubMed]

203. Gluud, L.L.; Dam, G.; Borre, M.; Les, I.; Cordoba, J.; Marchesini, G.; Aagaard, N.K.; Risum, N.; Vilstrup, H. Oral branched-chain amino acids have a beneficial effect on manifestations of hepatic encephalopathy in a systematic review with meta-analyses of randomized controlled trials. J. Nutr. 2013, 143, 1263-1268. [CrossRef]

204. Bianchi, G.P.; Marchesini, G.; Fabbri, A.; Rondelli, A.; Bugianesi, E.; Zoli, M.; Pisi, E. Vegetable versus animal protein diet in cirrhotic patients with chronic encephalopathy. A randomized cross-over comparison. J. Intern. Med. 1993, 233, 385-392. [CrossRef]

205. Merli, M.; Iebba, V.; Giusto, M. What is new about diet in hepatic encephalopathy. Metab. Brain Dis. 2016, 31, 1289-1294. [CrossRef]

206. Amodio, P.; Bemeur, C.; Butterworth, R.; Cordoba, J.; Kato, A.; Montagnese, S.; Uribe, M.; Vilstrup, H.; Morgan, M.Y. The nutritional management of hepatic encephalopathy in patients with cirrhosis: International Society for Hepatic Encephalopathy and Nitrogen Metabolism Consensus. Hepatology 2013, 58, 325-336. [CrossRef] 